\title{
TWO ANCIENT NEAR EASTERN TEMPLES WITH BENT AXIS IN THE EASTERN NILE DELTA ${ }^{1}$
}

By Manfred Bietak

Excavations at Tell el-Dabca and its environment (Fig. 1) between 1966 until now have revealed several temples: ${ }^{2}$ The memorial temple for Amenemhat I at CEzbet Rushdi from the late $12^{\text {th }}$ Dynasty, ${ }^{3}$ a sacred precinct with temples of Near Eastern and Egyptian types found at Tell el-Dabca itself from the time of the $14^{\text {th }}$ and $15^{\text {th }}$ Dynasties (Fig. 2) ${ }^{4}$ and remains of another temple from the time of the $15^{\text {th }}$ Dynasty west of the Tell. In this paper, I would like to concentrate on the sacred precinct as one of its temple shows a close resemblance to one of the temples of the Old Kingdom ${ }^{5}$ found by the Dutch expedition at Tell Ibrahim Awad under Willem van HAarlem and bears all signs of Ancient Near Eastern origin.

\footnotetext{
1 This article was originally conceived as a contribution to the conference on Egyptian Temples at the Netherlands/Flemish Institute in Cairo in January 2003. That is why it was written in English. I would like to thank my colleague Willem van Haarlem for inviting me to this meeting. As I could not travel to Cairo because of prior engagements in Vienna, my paper was delivered by my colleague Irene Forstner-Müller in my absence. No proceedings of this conference are intended to be published. That is why I sent this contribution for publication in Egypt and the Levant where also the temples of the Dutch excavations at Tell Ibrahim Awad were published; see n. 5. For English editing I am grateful to Adrian and Dagmar Melman, Vienna.

${ }^{2}$ On the site in general see M. BIETAK, Avaris, The Capital of the Hyksos - Recent Excavations at Tell el-Dabca, British Museum Publications. London 1996; IDEM, The Center of the Hyksos Rule: Avaris (Tell el-Dab'a), in: The Hyksos: New Historical and Archaeological Perspectives, ed. by E.D. Oren, University Museum Symposium Series, Philadelphia 1997, 78-140; IDEM, Une citadelle royale à Avaris de la première moitié de la XVIII ${ }^{\mathrm{e}}$ dynastie et liens avec le monde minoen, in: L'acrobate au taureau: Les découvertes de Tell el-Dab'a et l'archéologie de la Méditerranée orientale, Actes du colloque organisé au musée du Louvre par le Service culturel le 3 décembre 1994, ed. par A. CAubet, Paris 1999: Musée du Louvre, 29-81; IDEM, Dabca, Tell ed, in: The Oxford Encyclopedia of Ancient Egypt, ed. by D.B. REDFord, vol. I, New York-Oxford: Oxford Univ. Press 2001, 351-354.

3 S. ADAM, Report on the Excavations of the Department of Antiquities at Ezbet Rushdi, ASAE 56 (1959), 207-226; M. BIETAK \& J. DORnER, Der Tempel und die Siedlung des Mittleren Reiches bei cEzbet Ruschdi -

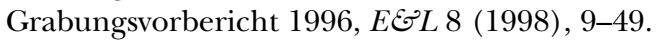

The core of the sacred precinct consisted of an area of c. $83 \times 25 \mathrm{~m}$ (Fig. 3). It is situated in the eastern part of the town which can be identified as Avaris and the southern part of Piramesse ${ }^{6}$ and dates to c. 1700-1650 B.C. (ph. F and E/3) - which is shortly before the Hyksos Period. The population at this site had been of Near Eastern origin since the late $12^{\text {th }}$ Dynasty and went on to become the catalyst for rule by the Hyksos (c. 1640-1530 B.C.). The main temple of this district had been kept in operation throughout the period and, according to offering deposits of the $18^{\text {th }}$ Dynasty, right into the time of the New Kingdom. ${ }^{7}$ The site was left intact until the end of the $20^{\text {th }}$ Dynasty and it was not until the

${ }^{4}$ Preliminary reports: M. BIETAK, Avaris and Piramesse, Archaeological Exploration in the Eastern Nile Delta. Ninth Mortimer Wheeler Archaeological Lecture, The British Academy, Oxford 1981, 247-256; IDEM, Tell el-Dab $a$ V, Ein Friedhofsbezirk der Mittleren Bronzezeitkultur mit Totentempel und Siedlungsschichten, UZK VIII, Vienna 1991, 21-24; IDEM, Avaris, The Capital of the Hyksos, London 1996, 36-48, figs. 30-32, pls. 13-17.

${ }^{5}$ D. EIGNER, Tell Ibrahim Awad: Divine Residence from

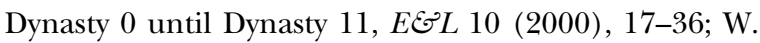
VAN HAARLEM, Les fouilles de Tell Ibrahim Awad (delta oriental du Nil): Resultats récentes, BSFE 141 (1998), 8-18; IDEM, The Excavations at Tell Ibrahim Awad (Eastern Nile Delta): Recent Results, in: Proceedings of the Seventh International Congress of Egyptologists, Cambridge, 3-9 September 1995, ed. by C.J. EYRE, Leuven 1998, 509-513; IDEM, An Introduction to the Site of Tell Ibrahim Awad, EELL 10 (2000), 13-16.

${ }^{6}$ For the identification see L. HABACHI, Khatacana - Qantir, Importance, ASAE 52 (1954), 443-559; IDEM, Tell el$D a b^{c} a$ I, Tell el-Dabc $a$ and Qantir, The Site and its Connection with Avaris and Piramesse, UZK II, Vienna 2001; J. VAN Seters, The Hyksos, A New Investigation, New Haven and London 1966; M. BIETAK, Tell el-Dabca II, Der Fundort im Rahmen einer archäologisch-geographischen Untersuchung über das ägyptische Ostdelta, UZK I, Vienna 1975; IDEM, Avaris and Piramesse, Archaeological Exploration in the Eastern Nile Delta, Mortimer Wheeler Archaeological Lecture 1979, Oxford 1981 (reprint from Proceedings of the British Academy 65, 1979, 225-289).

7 V. Müller, Offering Deposits at Tell el-Dabca, in: Proceedings of the Seventh International Congress of Egyptologists, Cambridge, 3-9 September 1995, ed. by C.J. EYRE, OLA 82, Leuven 1998, 793-803, EADEM, Bestand und Deutung der Opferdepots bei Tempeln in Wohnbereichen und 


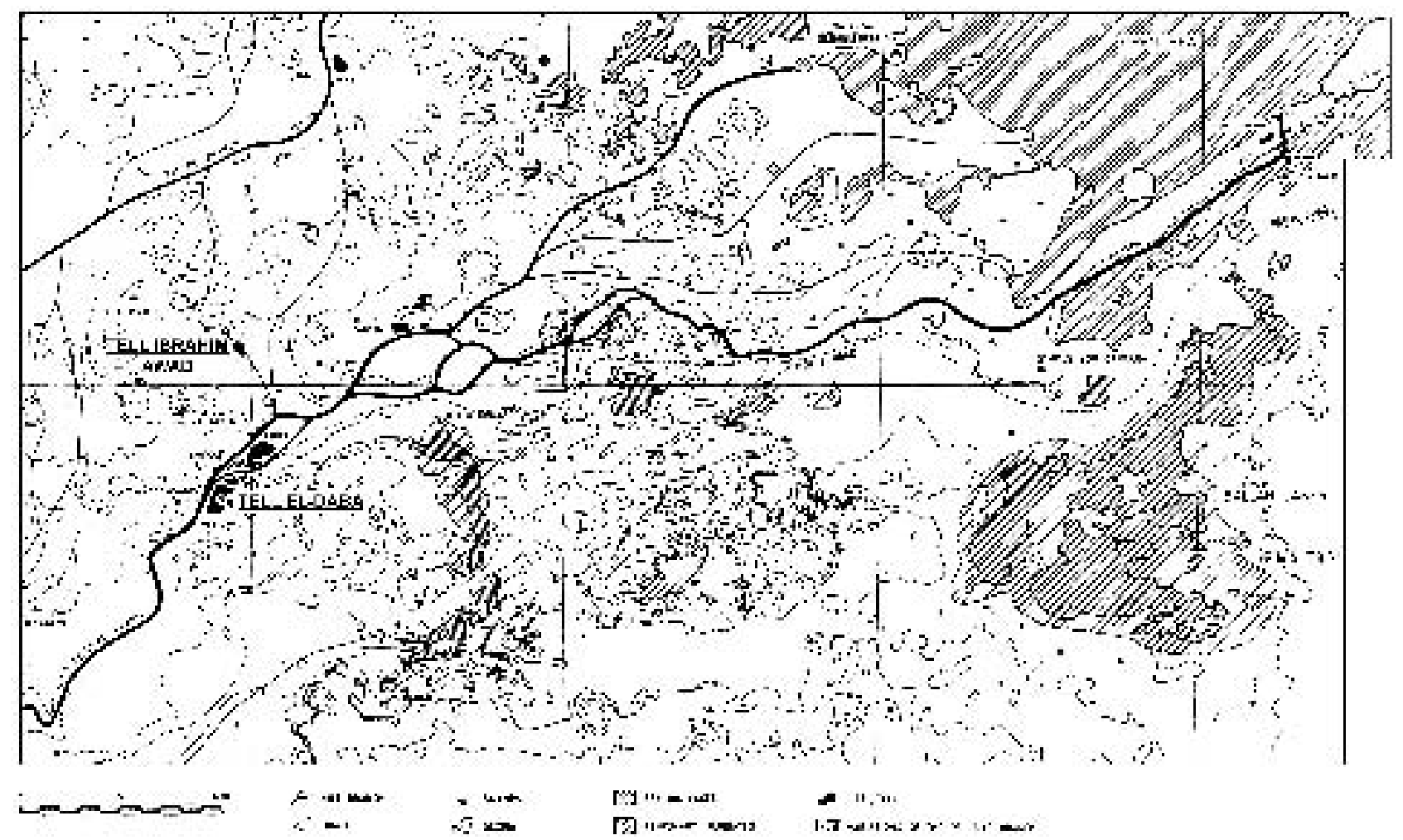

Fig. 1 Map of the north-eastern Nile Delta, showing the sites of Tell el-Dabca and Tell Ibrahim Awad with reconstructed historical water system (after BIETAK, Tell el-Dabc $a$ II, fig. 10)

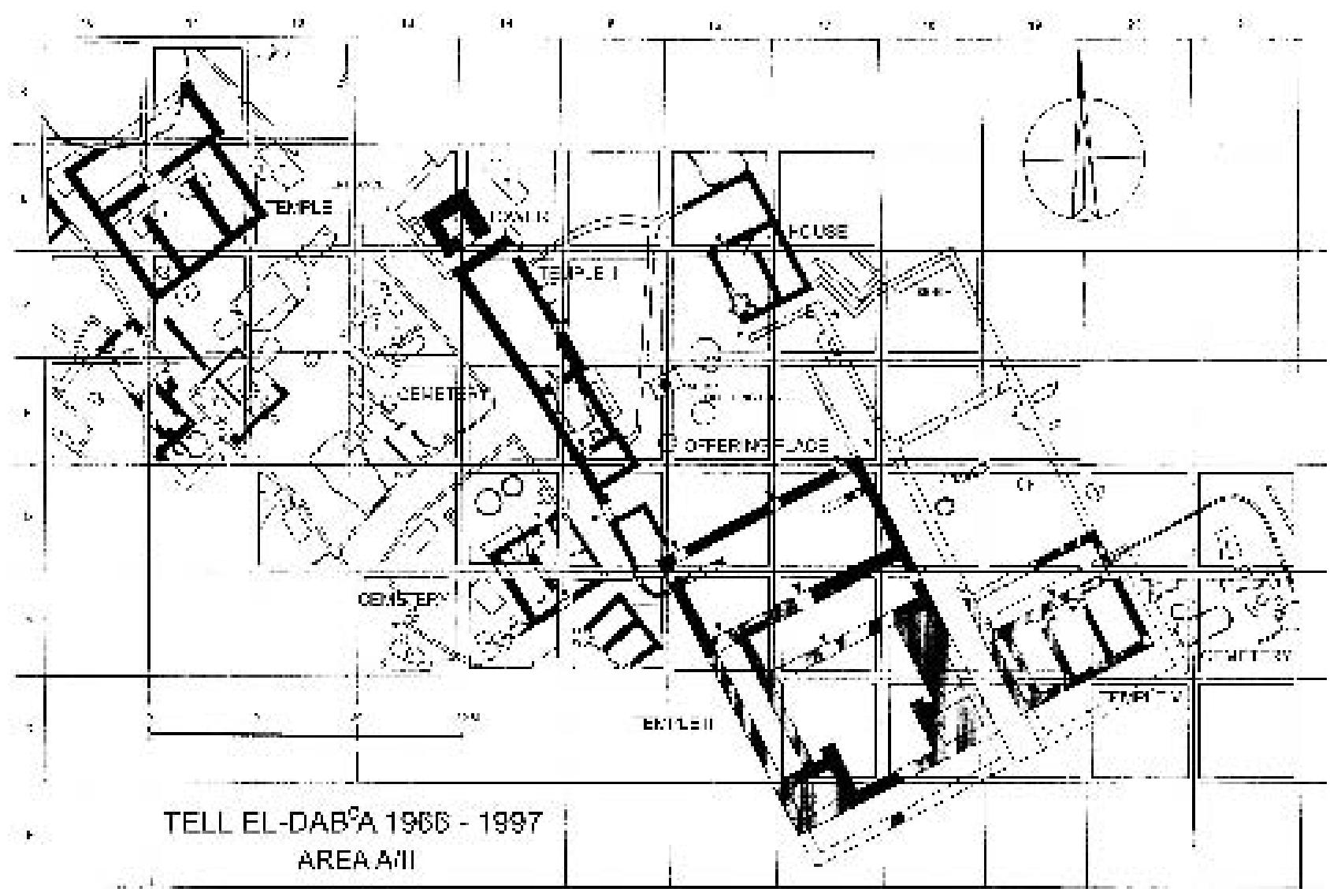

Fig. 2 The sacred precinct from the Second Intermediate Period at Tell el-Dabca (after BIETAK, Tell el-Dabc $a V$, fig. 3, with additions by I. FORSTNER-MÜLLER) 


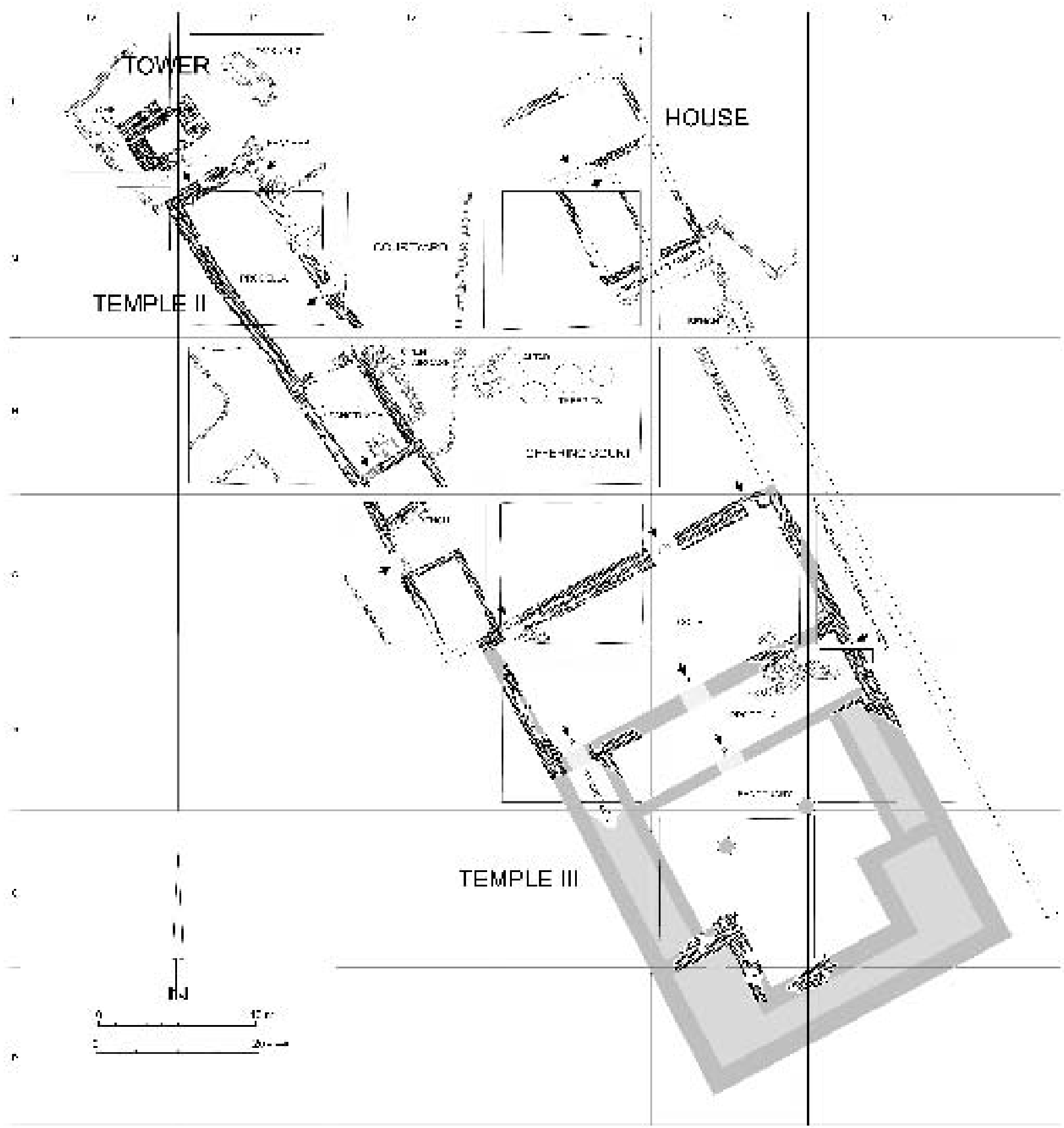

Fig. 3 Core of the sacred precinct at Tell el-Dabca (scanned from the original excavation documentation by N. MATH) 
Third Intermediate Period that secular buildings came to take pride of place. ${ }^{8}$

The precinct consists of a main temple (Temple III) in the south (Fig. 3) in front of which there was an offering place with a bamah, built of mudbrick. Pits around this place and charred acorns in the ash remains on top of the bamah are reason to believe that oaks were planted there providing shade. The offering place leads to a building which looks like a house. We may assume that it used to serve for ritual meals. ${ }^{9}$

The western edge of the precinct consisted of another temple (Temple II), a type of broadroom with bent axis and a tower. It was set back from the offering place of the main temple by a wall, which formed a triangular courtyard. It is perhaps no coincidence that the bamah in front of Temple III is situated just east of the sanctuary of Temple II.

Several cemeteries, each with mortuary chapels, surrounded this precinct (Fig. 2) ${ }^{10}$ While the temples mentioned were of Near Eastern type, the chapels clearly originate from Egyptian tradition. ${ }^{11}$ The chapel (Temple V), built parallel and east of the main temple (III), stands right out. It had also an offering court in the north with an altar and a second courtyard in the north with piles of broken pottery from ritual meals there. ${ }^{12}$ This mortuary chapel was arranged as if it were a twin temple to Temple III, the cemetery being annexed east of the chapel. Another cemetery followed to its north and is only partly excavated. The other cemeteries were arranged within the same precincts as their chapels (precincts II and IX).

This article focuses on Temple II (Figs. 4a-b, 5). It is aligned NNW-SSE, opening east-north-east. It has phases of repair and partial renewal that cannot be canvassed here in detail. The shrine originally used to be a longroom building with a door in the north and a cult podium attached to its southern wall. As only ex voto a harpoon head of copper was buried under the podium which is positioned asymmetric in order to give way to a door leading to another room in the south, most probably a kind of sacristy for storing cult paraphernalia. Later a broadroom with the façade to the east-north-east came to be added, thus creating a temple with a bent axis. The theory cannot be discounted that this had first been the original design of the temple that supplanted a broadroom originally made of wood and reed attached to the mudbrick shrine.

The main entrance of the broadroom is situated at the northern end of the eastern long wall. A second door is located nearer the centre of this wall, but it is smaller in size and is not designed with the purpose of giving access to the temple. As sole access, it leads to a closed triangular courtyard of unknown purpose, but it is unknown whether this was the original arrangement. The tomb at the northern edge of this courtyard dates only as far as the end of the operational period of the temple (ph. E/2), perhaps even after it had fallen into disrepair. A staircase added east of the temple, leading
Gräbern der zweiten Zwischenzeit in Tell el-Dabca, in: Social Aspects of Funerary Culture in the Egyptian Old and Middle Kingdoms, Proceedings of the International Symposium held at the Leiden University 6-7 June, 1996, ed. by: H. Willems, OLA 103, Leuven 2001, 175-204; EADEM, Opfergruben der Mittleren Bronzezeit in Tell el-Dabca, unpublished dissertation at the Univ. Göttingen 1996 (publication in preparation for UZK, Vienna).

8 Unpublished results of the excavations at Tell el-Dabca.

9 M. BIETAK, The Function and some Architectural Roots of the Fosse Temple at Lachish, Aharon Kempinski Memorial Volume, Studies in Archaeology and Related Disciplines, ed. by E.D. Oren and S. AhITUV, Beer Sheva XV, Beer Sheva 2002, 56-85; IDEM, Temple or 'Bêt Marzeah'?, in: Symbiosis, Symbolism and the Power of the Past: Canaan, Ancient Israel and their Neighbors, From the Late Bronze Age through Roman Palestine, The W.F. Albright Institute of Archaeological Research and the American Schools of Oriental Research Centennial Symposium, Israel Museum, Jerusalem, May 29-31, 2000, ed. by W.G. Dever and S. Gitin, Winona Lake, Ind. 2003, 155-168.
10 M. BIETAK, Tell el-Dabc $a$ V, Ein Friedhofsbezirk mit Totentempel der Mittleren Bronzezeit im östlichen Nildelta, UZK VIII, Vienna 1991, 21-24, fig. 3; I. ForstNer-MÜlleR, Vorbericht der Grabung im Areal A/II in Tell el-Dabca, EE⿱乛⿻上 11 (2001), 197-220, fig. 1; EADEM, Die Gräber des Areals A/II von Tell el-Dabca, unpublished dissertation at Univ. Vienna 2002 (publication in preparation at UZK).

11 M. BIETAK, Kleine ägyptische Tempel und Wohnhäuser des späten Mittleren Reiches - Zur Genese eines beliebten Raumkonzeptes von Tempeln des Neuen Reiches, in: Hommages à Jean Leclant, ed. by N. GRIMAL, vol. I, BdÉ 106/1, IFAO, Cairo 1994, 414-435; IDEM, Götterwohnung und Menschenwohnung, Die Entstehung eines Tempeltyps des Mittleren Reiches aus der zeitgenössischen Wohnarchitektur, ein Vorbericht, in: Ägyptische Tempel - Struktur, Funktion, Programm. Akten der Ägyptologischen Tempeltagungen in Gosen und Mainz 1992, ed. by R. Gundlach \& M. Rocholz, HÄB 37, Hildesheim 1994, 13-22.

12 V. MüLLER, forthcoming, n. 7 end. 


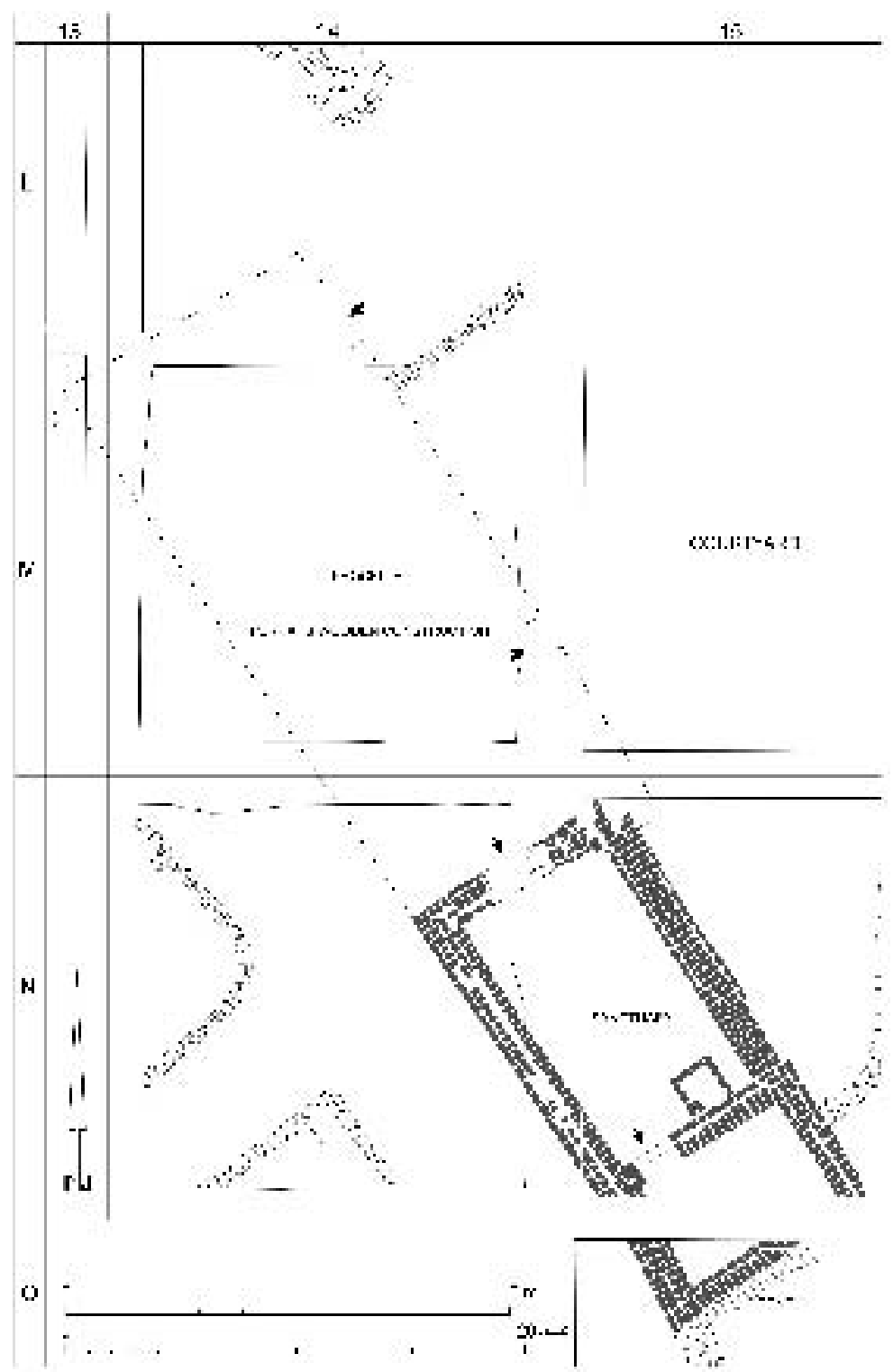

Fig. 4a Temple II at Tell el-Dabca, oldest phase (graphics by N. MaTH after field drawing) 


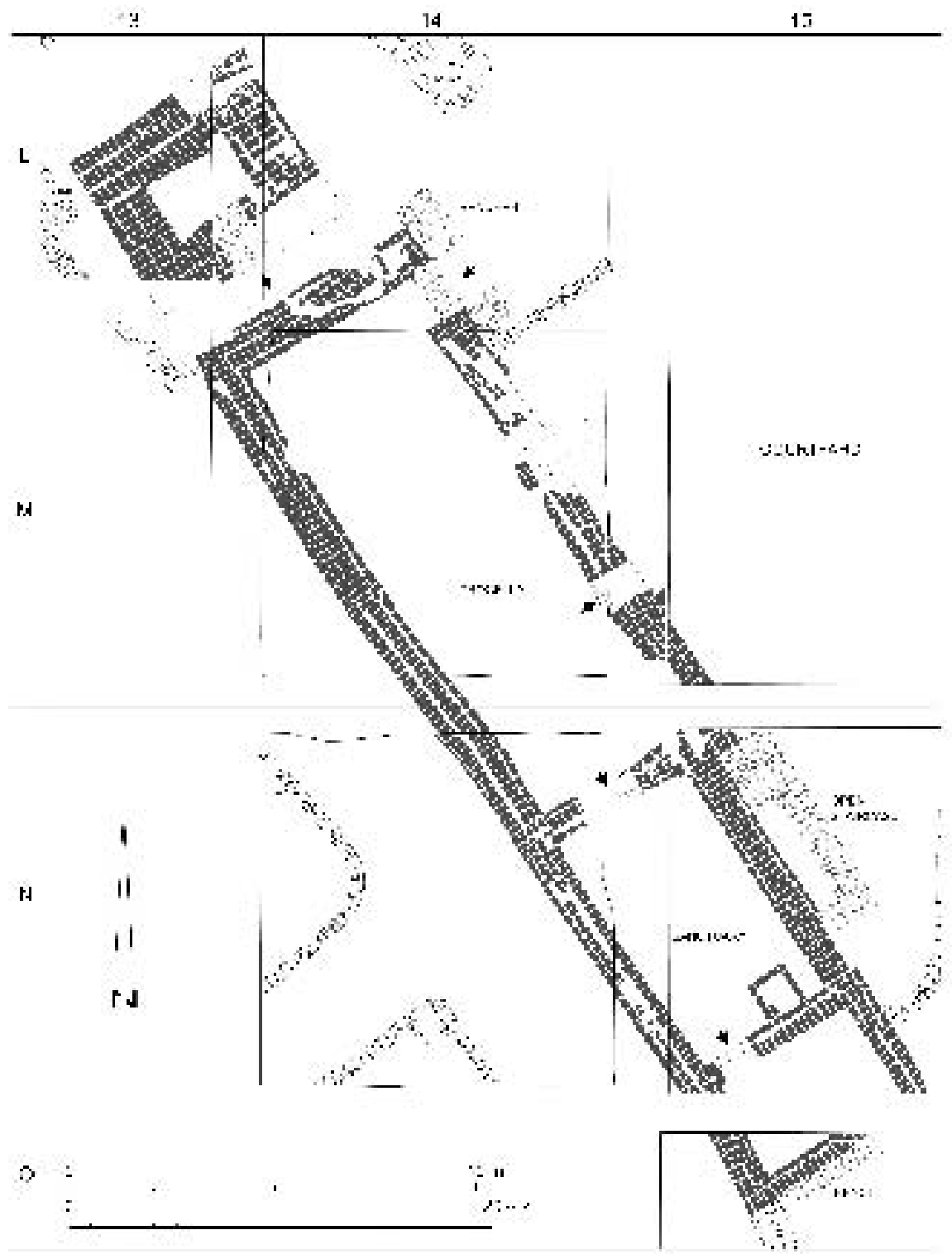

Fig. 4b Temple II with bent axis at Tell el-Dabca, middle phase (graphics by N. MATH after field drawing) 


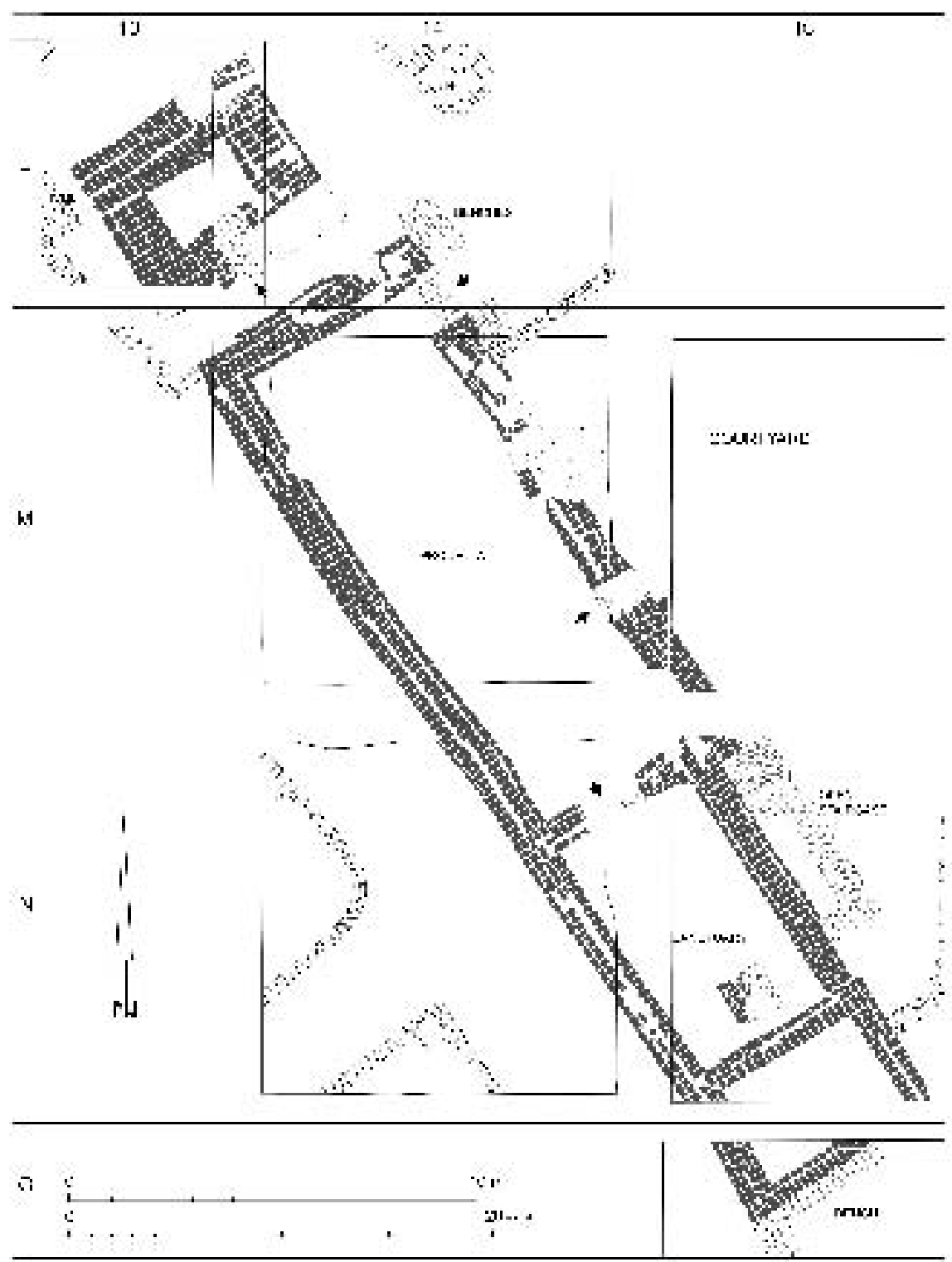

Fig. 5 Temple II in its later phase (graphics by N. MATH after field drawing) 
from the south to the roof of the broadroom, was accessible from this courtyard.

At a late phase, the southernmost room, the sacristy, had been abandoned and the south wall of the cult room closed. The cult podium, now square and solidly filled, was taken off the south wall and moved in the direction of the middle axis of the shrine (Fig. 5). To the north of this temple there are remains of a tower with sturdy walls. It is situated right inside the forecourt of the sacred precinct which is enclosed by a mudbrick wall running off the north-western corner of the Temple II. On both sides of this tower were found tombs belonging to ph. E/3, the main period of this temple. They may be part of a cemetery encroached upon by the temple with its tendency to jut out northwards. Nevertheless, this kind of neighbourhood suggests a funerary purpose, as does the rest of the sacred precinct (s. above).

This broadroom temple with bent axis had been added to the sacred precinct in the time of phase E/3 together with temple V. Main Temple III had been already constructed during ph. F. It is striking that our Temple II very much resembles temple phases 2b-c from Tell Ibrahim Awad (Figs. 6, 7). ${ }^{13}$ This temple - that is much older and dates to the Old Kingdom - basically represents a similar type of shrine, has the same alignment as Temple II at Tell el-Dabca and may even have served a similar purpose. ${ }^{14}$ This temple also has a broadroom with bent

13 Supra n. 5.

14 Temple II at Tell el-Dabca was part of a sacred precinct surrounded by cemeteries and there were even two tombs within the wall compound belonging to Temple II (Figs. 2-3). The early Middle Kingdom Temple of Tell Ibrahim Awad had tombs from the same period in its immediate vicinity. As the temples show a succession going back to Predynastic times, the discovery of a tomb of the $1^{\text {st }}$ Dynasty in the immediate vicinity of the temples may be taken as an indication that funerary rites may also have been performed in the older temples. No tomb was found from the times of our bentaxis temple. An attempt at an ultimate functional analysis would be feasible only after it was possible to unearth other areas in the vicinity of the temples.

15 A. BEN Tor, Plans of Dwellings and Temples in Early Bronze Age Palestine, EI 11 (1973), 25, 97-98 (Hebr.); Z. Herzog, Broadroom and Longroom House Type, TA 7 (1980), 86-88; G.R.H. WRIGHT, Ancient Building in South Syria and Palestine, Handbuch der Orientalistik, VII. Abt., Kunst und Archäologie, Bd. I, Der Alte Orient, 2. Abschn., Die Denkmäler, ed. by B. HroudA, B Vorderasien, Lieferung 3, Leiden-Cologne 1985, axis and faces east-south-east. Its entrance is situated - as in Temple II of Tell el-Dabca - at the northern end of its eastern long wall, the cultic axis then bending $90^{\circ}$ towards the south. However, the Holy of the Holies is neither accommodated within an extra room south of the temple, nor at the southern short wall, but was attached at the centre of the rear wall of the same room, formed by an L-shaped wall, abutting one end on the rear wall and accessible only from the north. Another remarkable feature is the closed narrow corridor behind the rear wall that seems to have been opened on rare occasions only to deposit or bury cult paraphernalia that had gone out of use.

The temple with a broadroom and a bent axis is not otherwise known in Egypt. The broadroom temple with straight axis is the predominant type in the Early Bronze Age in Canaan ${ }^{15}$ where the entrance is, however, usually in the middle of the long facing wall and the cult podium is opposite to the door at the middle of the rear wall. Most of those early temples in Canaan adhere to this scheme, starting from as early as the Chalcolithic age. ${ }^{16}$ Some of the archetypal examples are the twin temples at Arad, ${ }^{17}$ the sanctuary at Bab el-Drac ${ }^{18}{ }^{18}$ "le batiment blanc" at Tel Yarmut, ${ }^{19}$ the Acropolis Temple at El-Tell (Ai), which shares with the temple at Tell Ibrahim Awad the narrow corridor behind the rear wall (Fig. 8). ${ }^{20}$ This feature can also be found with the antae-temples at Megiddo. ${ }^{21}$ Other broad-

231-232, figs. 123-129; A. KemPInSKI, Chalcolithic and Early Bronze Age Temples, in The Architecture of Ancient Israel, ed. by A. KeMPINSKI \& R. ReICH, Jerusalem 1992, 53-59.

16 D. Ussishrin, The 'Ghassulian' Temple in Ein Gedi and the Origin of the Hoard from Nahal Mishmar, Biblical Archaeologist 34 (1971), 23-39; IDEM, The Ghassulian Shrine at En Gedi, Tel Aviv 7 (1980), 1-44; A. KempInsKI, The Sin Temple at Khafaje and the En Gedi Temple, IEJ 22 (1972), 10-15.

17 R. Amiran, Early Arad, The Chalcolithic Settlement and the Early Bronze City, vol. I, First-Fifth Seasons of Excavations, 1962-1966, Jerusalem 1978, 38-41, 190-191.

18 W.E. Rast \& R.T. SCHAUb, Preliminary Report of the 1979 Expedition to the Dead Sea Plain, Jordan, BASOR 240 (1980), 30-32, fig. 7.

19 P. DE MiroschedjI, Yarmouth I, Rapport sur les trois premières campagnes de fouilles à Tel Yarmouth (Israël) (1980-1982), Paris 1988, 38-41, fig. 2, pl. 8.

$20 \mathrm{~J}$. Marquet-Krause, Les fouilles de cAy (et-Tell), 1932-1935, Paris 1949, 10-12, 14-16, pl. 92.

21 Cf. n. 26. 

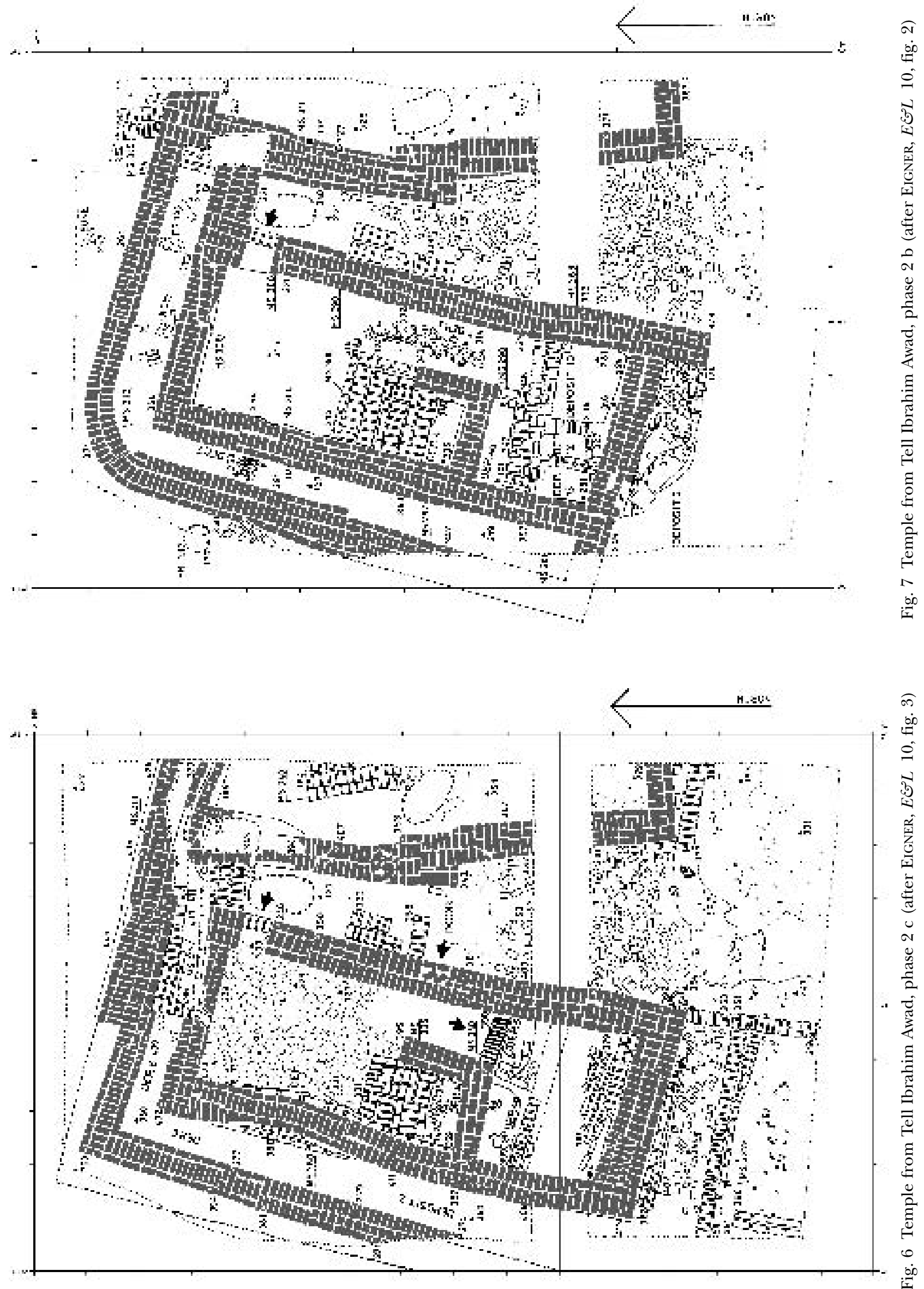


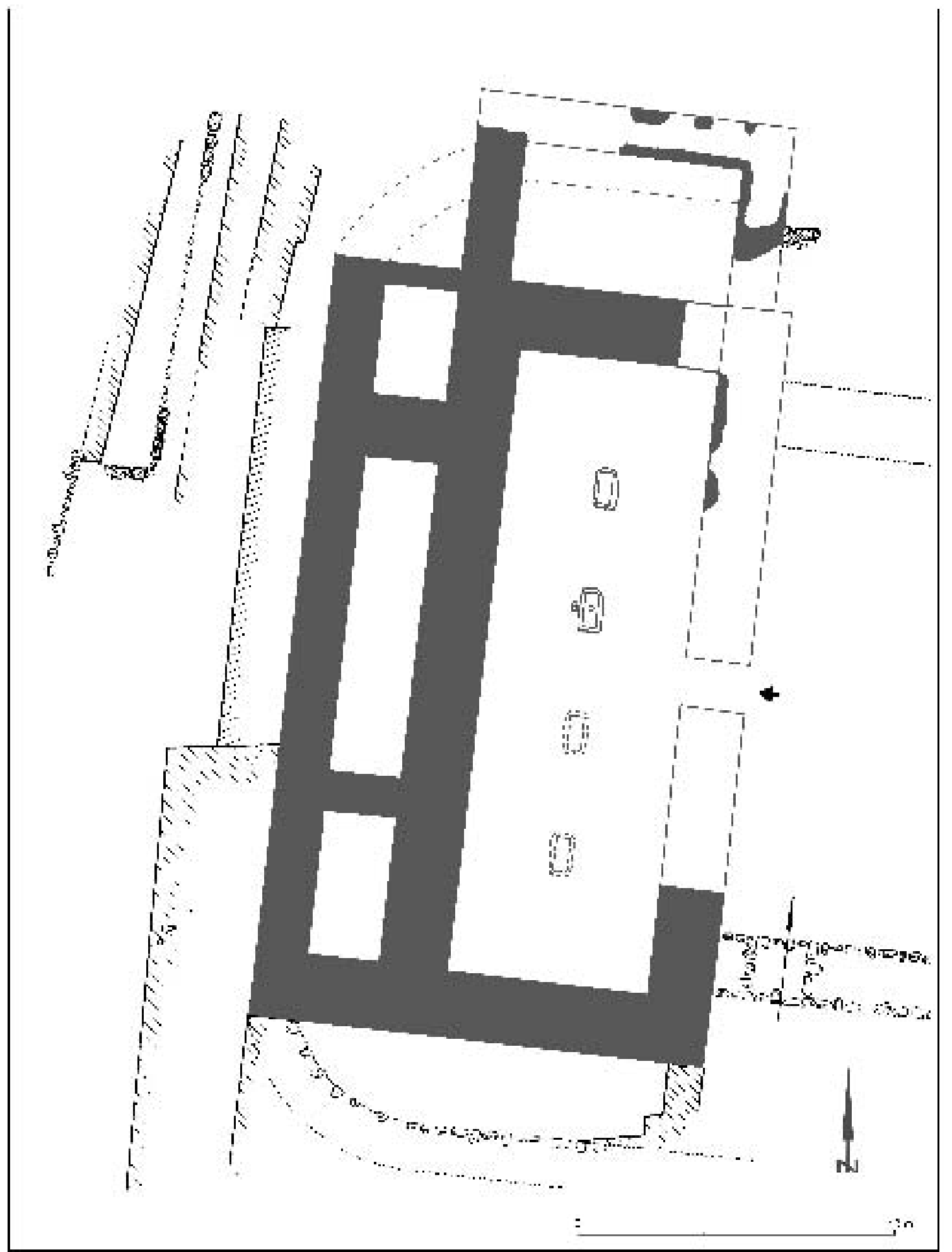

Fig. 8 The Akropolis Temple at El Tell (Aï) (after MarQUeT-Krause, Les fouilles de cAy (et-Tell), 1932-1935, pl. 92) 
room temples are the twin temples 4047 and 4050 of str. XIX at Megiddo, ${ }^{22}$ probably the badly damaged temple of str. XVIII at Megiddo, ${ }^{23}$ the Chalcolithic (pre-urban) $\mathrm{Ba}^{\mathrm{C}}$ alat Temple at Byblos ${ }^{24}$ and, to a certain extent, the pro-cella of the Obelisk Temple, which dates back to the MB I-Period and that is bound to be a broadroom with an entrance through one long wall and an exit door through the other leading to the open obelisk shrine. ${ }^{25}$ It looks like a broadroom temple.

This kind of temple very often has a row of pillars along its long axis. To a certain extent the later Megiddo Porch Temples in antis 4040, 5192 of str.
XV and Temple 5269 (str. XVII-XIVb) with only a pair of columns also follow this scheme. ${ }^{26}$

Temples with bent axis as at Tell el-Dabca and Tell Ibrahim Awad are rare in Canaan, but they did exist in the Early Bronze Age. They had only a single room like the temple at Tell Ibrahim Awad.

The first example is the Temple of Jericho, level VII (EB I).$^{27}$ It has a broadroom measuring c. $6.5 \times$ $3 \mathrm{~m}$ (Fig. 10). It is aligned the same way as the temples at Tell Ibrahim Awad and Tell el-Dabca NNWSSE, with its front facing east. However, the entrance is not at the northern but at the southern end of the front wall. The axis bends right, towards the north.

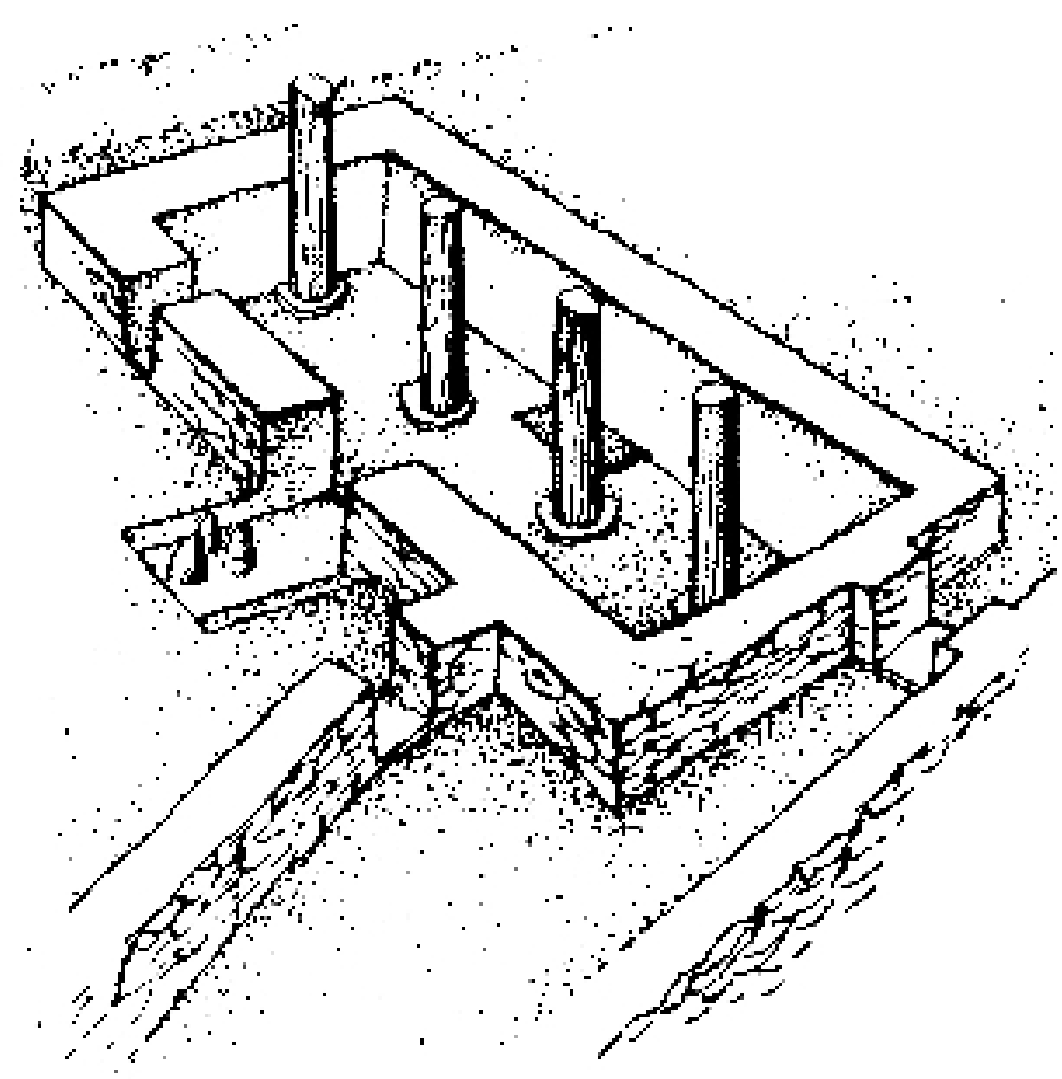

Fig. 9 Temple from Tel Yarmuth (after DE MiroshedjI, Tel Yarmout I, fig. 2)

22 G. Loud, Megiddo II, Chicago 1948, 61-70, figs. 135143, 390; I. DunaYevsky \& A. Kempinski, The Megiddo Temples, ZDMG 89 (1973), 167-172, and EI 11 (1973), 8-29, in Hebrew.

23 Loud, op. cit. fig. 391.

24 M. DunAnd, Fouilles de Byblos V, Paris 1973, 235-241, fig. 143.

25 M. Dunand, Fouilles de Byblos II, Paris 1950-1958, fig. 767; U. FinKBEINER, Untersuchungen zur Stratigraphie des Obelisken Tempels in Byblos, Bagdader Mitteilungen
12 (1981), 13-71, plans 1-13; TH. Busink, Der Tempel von Jerusalem, von Salomon bis Herodes, Eine archäologischhistorische Studie unter Berücksichtigung des westsemitischen Tempelbaus I, Leiden 1970, fig. 125.

${ }^{26}$ Loud, Megiddo II, figs. 180-181. For redating the temples see I. Dunayevsky \& A. Kempinski, op. cit. (n. 22), 167-172.

27 J. Garstang, Story of Jericho, ${ }^{2}$ London 1948, fig. 8; BusINK, op. cit., fig. 86. 


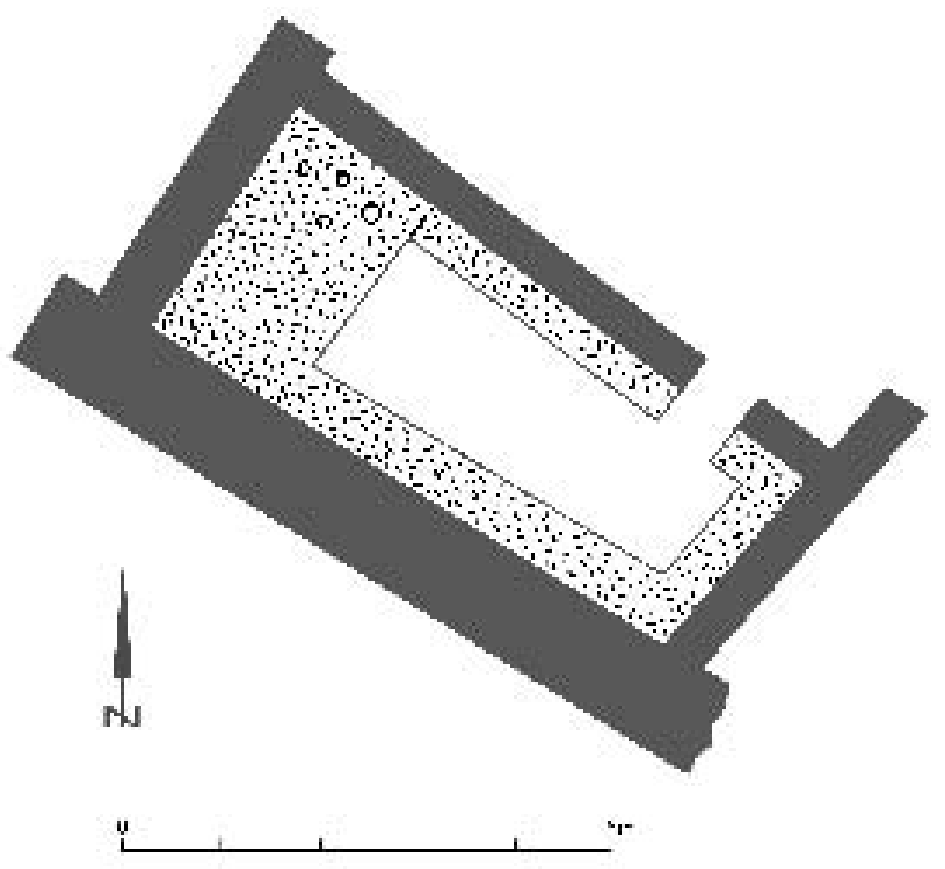

Fig. 10 Temple of Jericho, str. VII (after Garstang, Story of Jericho, fig. 8)

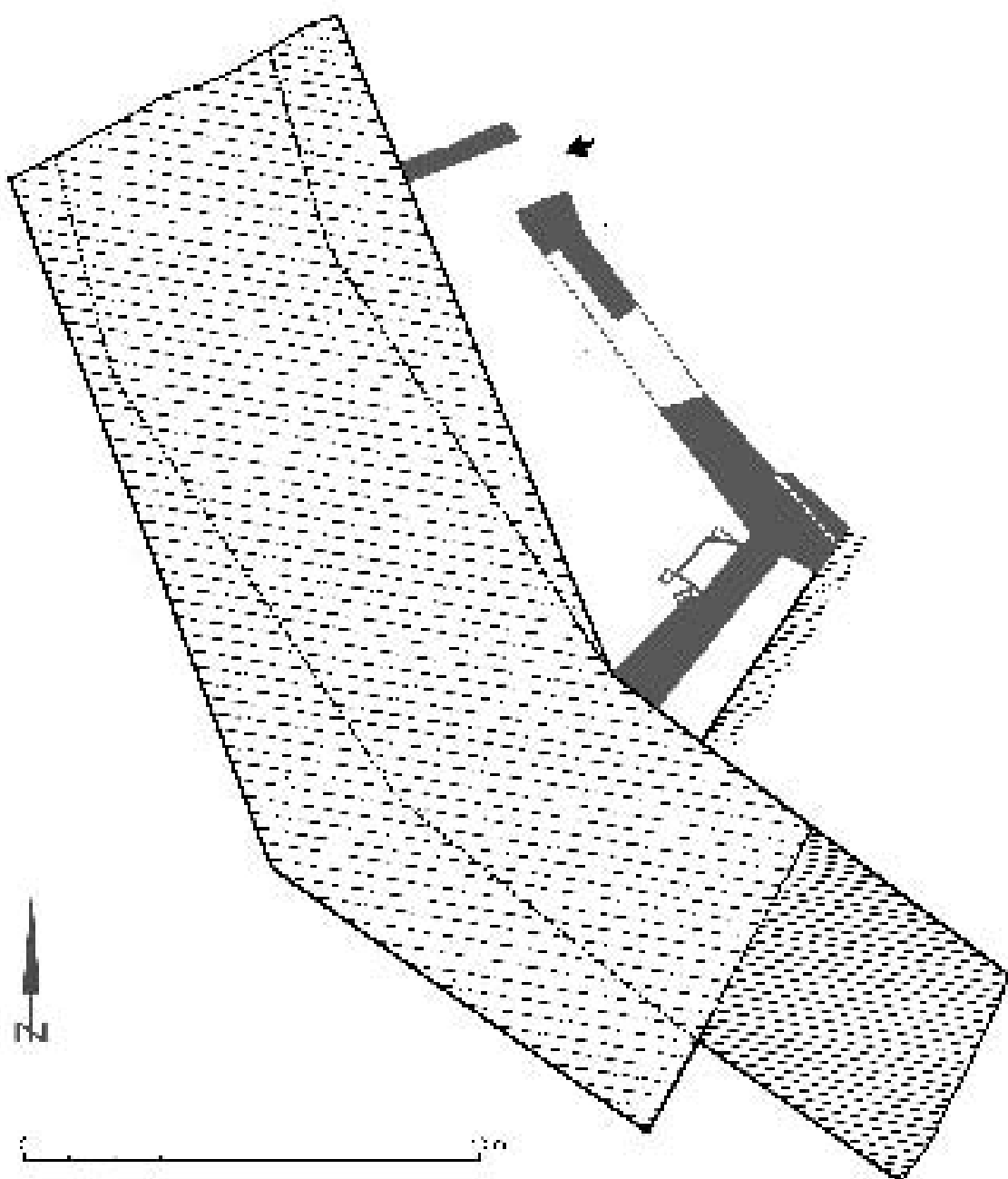

Fig. 11 The City Wall Temple C at El-Tell (Aï) (after MArQuet-Krause, Les fouilles de cAy (et-Tell), 1932-1935, pl. 98) 


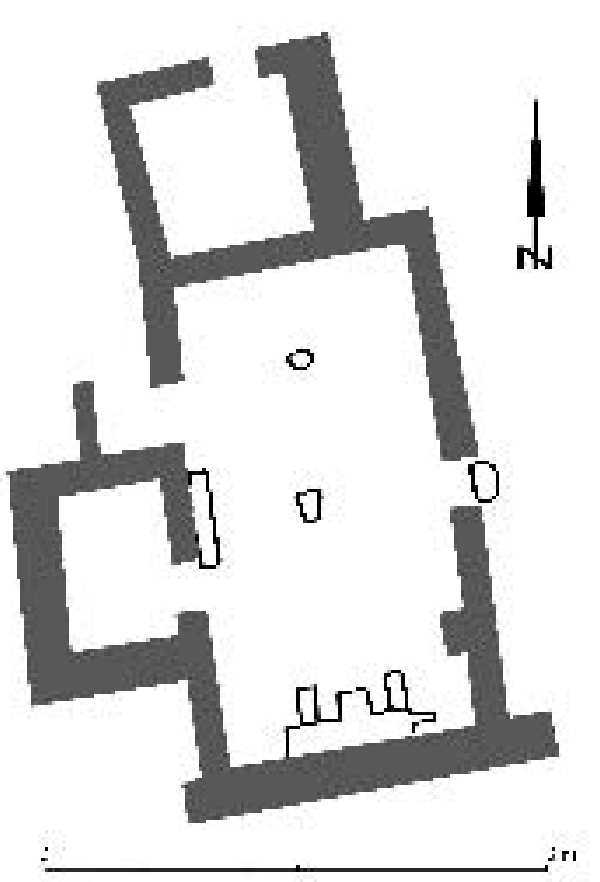

Fig. 12 Fosse Temple I at Tell el-Duweir/Lachish (after Tufnell, Inge \& HARding, Lachisch II, The Fosse-Temple. London 1940, pl. XVI)

All four sides of the room are lined with benches. Turning to the position of the cult podium, we can only conjecture that it must have been situated at the northern end of the room.

The second example from the Early Bronze Age is the City Wall Temple at El-Tell (Ai) of EB IIIb (Fig. 11). ${ }^{28}$ It backs onto the city wall and is again aligned NNE-SSW, with its long front wall facing east. Like the Tell Ibrahim Awad and the Tell el$\mathrm{Dab}^{\mathrm{c}} \mathrm{a}$ temple, it again has a left-bent axis.

The Middle Bronze Age Temple of Nahariya is considered to be a temple with bent axis ${ }^{29}$ with attached rooms behind the rear wall. It has a broad room (I) with access from the south. It is, however, unclear if the Holy of the Holies was situated at the back wall or in the attached room II for which no door has been found. In the former case it would have been a classical broadroom, in the second a temple with bent axis.

The issue is whether the earliest so-called Fosse Temple I (Fig. 12) ${ }^{30}$ at Tell el-Duweir/Lachish from LB I is one of the bent-axis type, ${ }^{31}$ as this building has the same distinct room annex in the north as its successors "Temples II-III" where they were bound to have been the entrance rooms. ${ }^{32}$ It is possible that this temple had several entrances and that the real significance of the layout of the oldest temple was missed by the excavators. The function of this building as a temple as well as of the "temple" of Nahariya as a building serving probably ritual meals deserves serious discussion. ${ }^{33}$

The temple with broadroom and bent axis, also called "Herdhaus" (hearth house) by WALTER ANDRAE $^{34}$ and ERNST HEINRICH, ${ }^{35}$ is considered by authorities to be of southern Mesopotamian origin. ${ }^{36}$ Good examples from the Early Dynastic Period (ED I) would include: the Small Temple from Khafadji with the door inserted in the northern section of the long façade, facing east-north-east with bent axis pointing south; it is the minimalist version of this type of single-shrine temple (Fig. 13a); in a later phase a broadroom vestibule was added to the entrance (Fig. 13b) and later the shrine was rebuilt with the same alignment and a courtyard attached, whilst in front of it there was another bent-axis room (Fig. 13c) ${ }^{37}$ In this version, the layout resembles the Nintu Temple at Khafadja (Fig. 14) with a double courtyard, back-toback, the western courtyard with two shrines facing each other over the courtyard - one with a niched façade. The cult podium is in both cases not in the south but in the north. ${ }^{38}$ Like Temple II (Fig. 4) at Tell el-Dabca, both have double doors. The other

\footnotetext{
28 J. Marquet-Krause, Les fouilles de ${ }^{c}$ Ay (et-Tell), 1932-1935, pl. 98/sanctuaire C; J.A. CAllaway, The Early Bronze Age Sanctuary at Aï, London 1972, fig. 8; Busink, op. cit. figs. $87,89$.

${ }^{29}$ J. Kaplan, Mesopotamian Elements in the Middle Bronze II Culture of Palestine, JNES 30 (1971), 293-307.

30 O. Tufnell, C.H. Inge \& L. Harding, Lachisch II, The Fosse-Temple, London 1940, pl. XVI.

31 So Wright, op. cit., 131, 221, 227, 501.

32 Tufnell, Inge \& HARding, op. cit., pls. LXVII, LXVIII.

33 Cf. n. 9.

34 W. ANDrae, Das Gotteshaus und die Urformen des Bauens im Alten Orient, Berlin 1930, $18 \mathrm{f}$.

35 E. HeInrich, Die Tempel und Heiligtümer im Alten
}

Mesopotamien, Typologie, Morphologie und Geschichte, Denkmäler antiker Architektur 14, Berlin 1982, $14 f$.

36 A. Kempinski, Chalcolithic and Early Bronze Age Temples, in The Architecture of Ancient Israel, ed. by A. KemPINSKI \& R. REICH, Jerusalem 1992, 59; HEINRICH, loc.cit. shows that this type exists already in the Djemdet Nasr time as the Sin Temple V and Temple in O43 at Khafadja, op. cit., 95 f., figs. 178, 179.

37 P. Delougaz \& S. Lloyd, Pre-Sargonid Temples in the Diyala Region, OIP 58, Chicago 1942, pl. 17 A, C, F.; HeInRICH, op. cit., 95f., 122f., figs. 178-181.

38 Delougaz \& Lloyd, op.cit., pl. 16; HeInRICH, op. cit., 123f., fig. 183. 

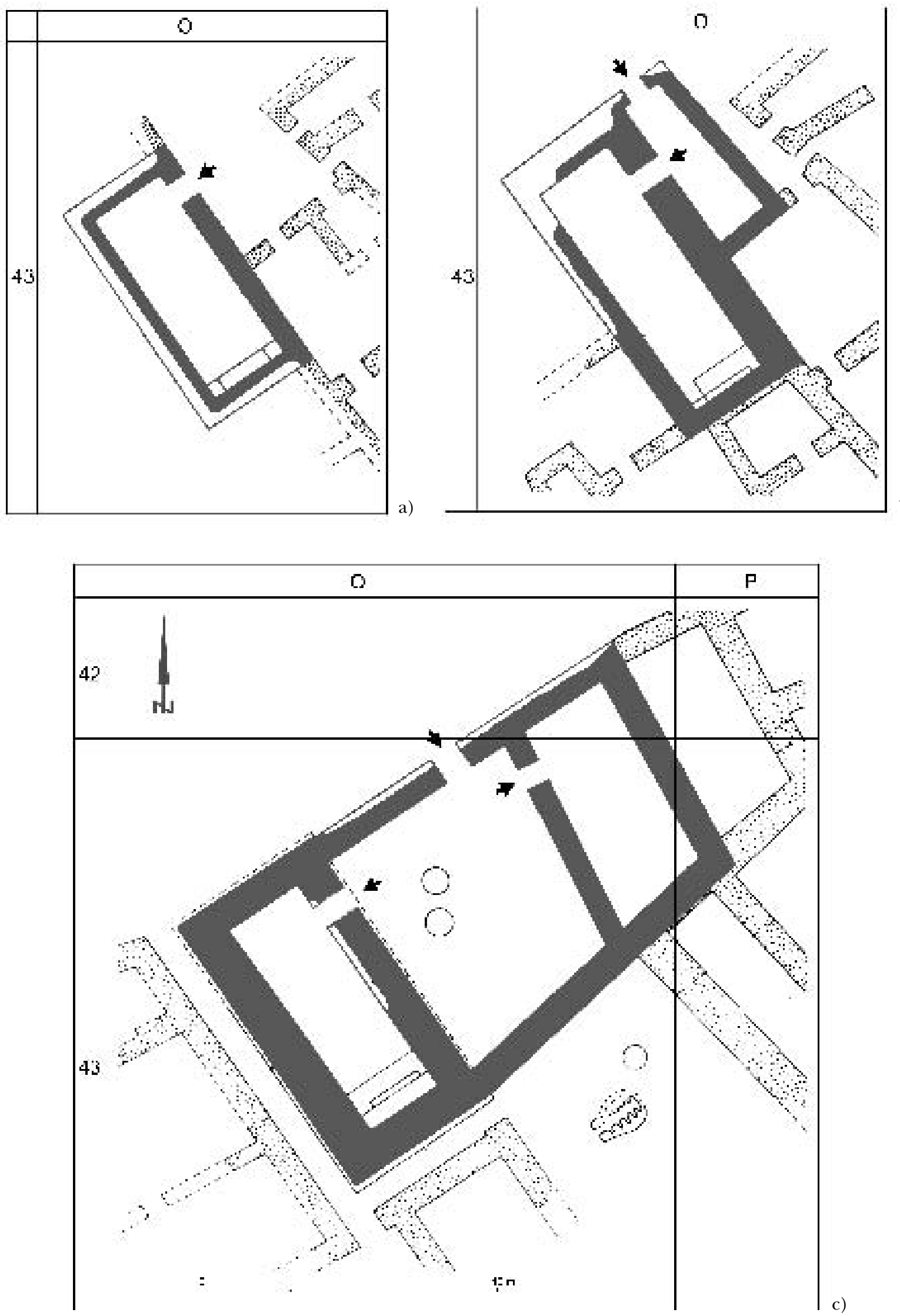

Fig. 13a-c The Small Temple at Khafadja, phases A, E, F (after HeInRICH, Tempel und Heiligtümer, figs. 178-181) 
court has another bent-axis temple with one door and with niched façade, facing north-north-east.

Another single-shrine temple is the Abu Temple from the Early Dynastic III Period (Fig. 15b) at Tell el Asmar (Eshnunna). ${ }^{39}$ Its niched façade faces north. The entrance is at the eastern end of the long northern wall, a second door near the cult podium leads into a linked room with thin walls, probably a sacristy. In the preceding two phases (Early Dynastic I?) of the Archaic Shrines I and II, the system is embedded in the core of a sprawling compound structure with a $180^{\circ}$ reversed alignment, the entrance in the south and the second door leading into an otherwise inaccessible room near the cult podium in the east (Fig. 15a). ${ }^{40}$ The two doors through the façade, the distant one as an entrance, the other near the cult podium leading into another linked room, resembles the configuration of Temple II at Tell el-Dab ${ }^{\mathrm{a}}$, the difference here being that the second door does not lead into a closed room but into an enclosed spot (Fig. 4) which is like the room inaccessible from anywhere else.

In our abridged survey of Near Eastern temples with bent axis, the Ishtar Temple of Assur in its several phases from the Early Dynastic III till the Ur III Period may be of consequence as far as we are concerned (Fig. 16). ${ }^{41}$ At this spot the temple is approached not from the east but the west, from the end furthest from the sanctuary. This one is set off as a room on its own. This room configuration can be compared to the one of Temple II at Tell el Dabca but the door or entrance is much wider, the alignment is $180^{\circ}$ reversed, and there is only one entrance. In both cases the axis bends to the left.

We have already referred several times to the two doors at some temples with bent axis, the purpose of which may have been to go into and out of the temple at cultic events. Most interesting is an Early Dynastic III temple with bent axis at Mari, belonging to Ninni-Zaza (Ishtar) (Fig. 17). ${ }^{42}$ The shrine is integrated into a larger building and borders a square courtyard with a processional path ${ }^{43}$ leading around the court, leaving the impression that, in this case, the shrine with its two doors is included in this processional path.

There are several more single-shrine temples with bent axis, some of which were integrated into larger palatial complexes of residential areas. To discuss all of them, especially examples later than our temples in Egypt, would be beyond the scope of this article. $^{44}$

Now for some final remarks on the supposed origins of the bent-axis temple. As clear prototypes of single-shrine temples are missing in the house architecture, HEINRICH postulated its origins as being from the "Mittelsaalhaus" (middle room house).$^{45}$ This type he explains by three broadroom units following each other with a dominating central room. The side stripes can be subdivided in this case. This specific type of house culminated as early as the fourth millennium in the typical Mittelsaal type of temple, also called Uruk temple which may have had access from several sides. ${ }^{46}$ As either of the two long walls of such temples often used to face a courtyard on one side, the inevitable result was a concentration of the only doors leading into the courtyards. The doors of Ziqqurat temples used to open up mainly onto the side of the access ramps. As the cult podium, as a rule, used to be set up against one of the small walls, the bent axis was a result of the trend to opening up the temple through one of its long walls.

Such a Mittelsaalhaus type of temple with a bent entrance system is known from Uruk times at the Painted Temple at Tell cUqair (Fig. 19). ${ }^{47}$ Although just over one-half of the building is excavated, the layout can be reconstructed as a Mittelsaalhaus, with two entrances from the side facing the north-east and bent axis to the cult podium on the right, to the north-west. It is unlikely that entrances could be reconstructed on the other side of this temple, situated on a Ziqqurrat, as the stepped approaches to this building were constructed from one side only.

A scale-down in the room programme inexorably

39 Delougaz \& Lloyd, op.cit., pl. 23A; HeinRich, op. cit., 126, fig. 186.

40 Delougaz \& Lloyd, op.cit., pls. 20B, 31B; HeinRich, op. cit., 94f. figs. 152, 154.

${ }^{41}$ W. ANDRAE, Die archaischen Ischtar-Tempel in Assur, WVDOG 39, Berlin 1922, pls. 2-7; HeINRICH, op. cit., fig. 243.

42 A. PArrot, Les temples d'Ishtarat et de Ninni-Zaza, Mission archéologique de Mari III, BAH 86, Paris 1967, 22-34,

figs. 14-23, pl. 2,3; HeINRICH, op. cit., 130-131 figs. 197, 202, 205.

43 The identification as processional path has been made by the excavators. (previous $\mathrm{n}$.)

${ }^{44}$ HeinRich, op. cit., figs. 198, 199, 201, 211-220, 271, 294.

${ }^{45}$ HeINRICH, loc. cit.

${ }^{46}$ HeInRICH, n. 35.

47 S. LLOYD, Report on the Excavations, JNES 2 (1943), 135-155, pls. 4-5; HeInRICH, op. cit., 96f., fig. 105. 


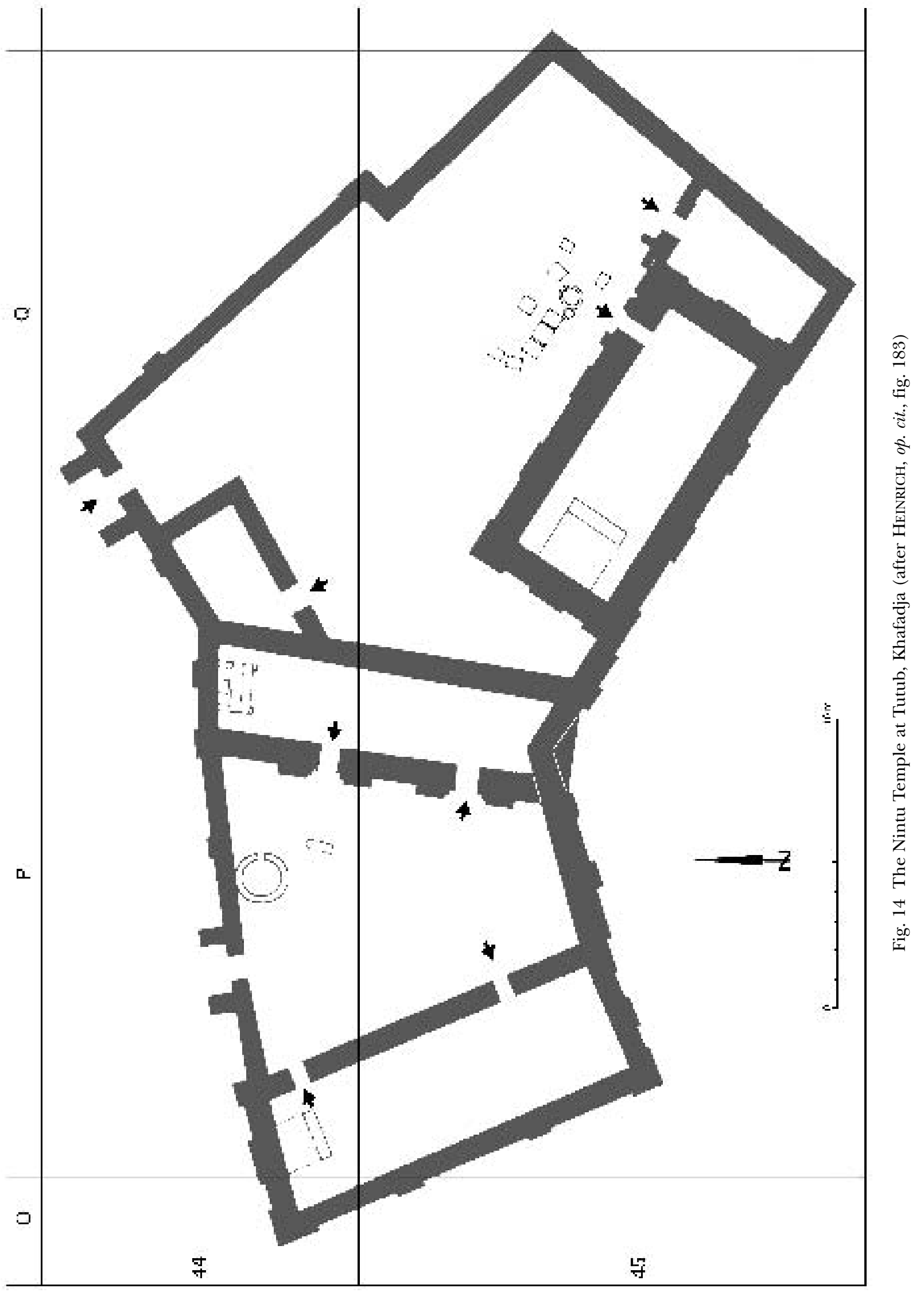




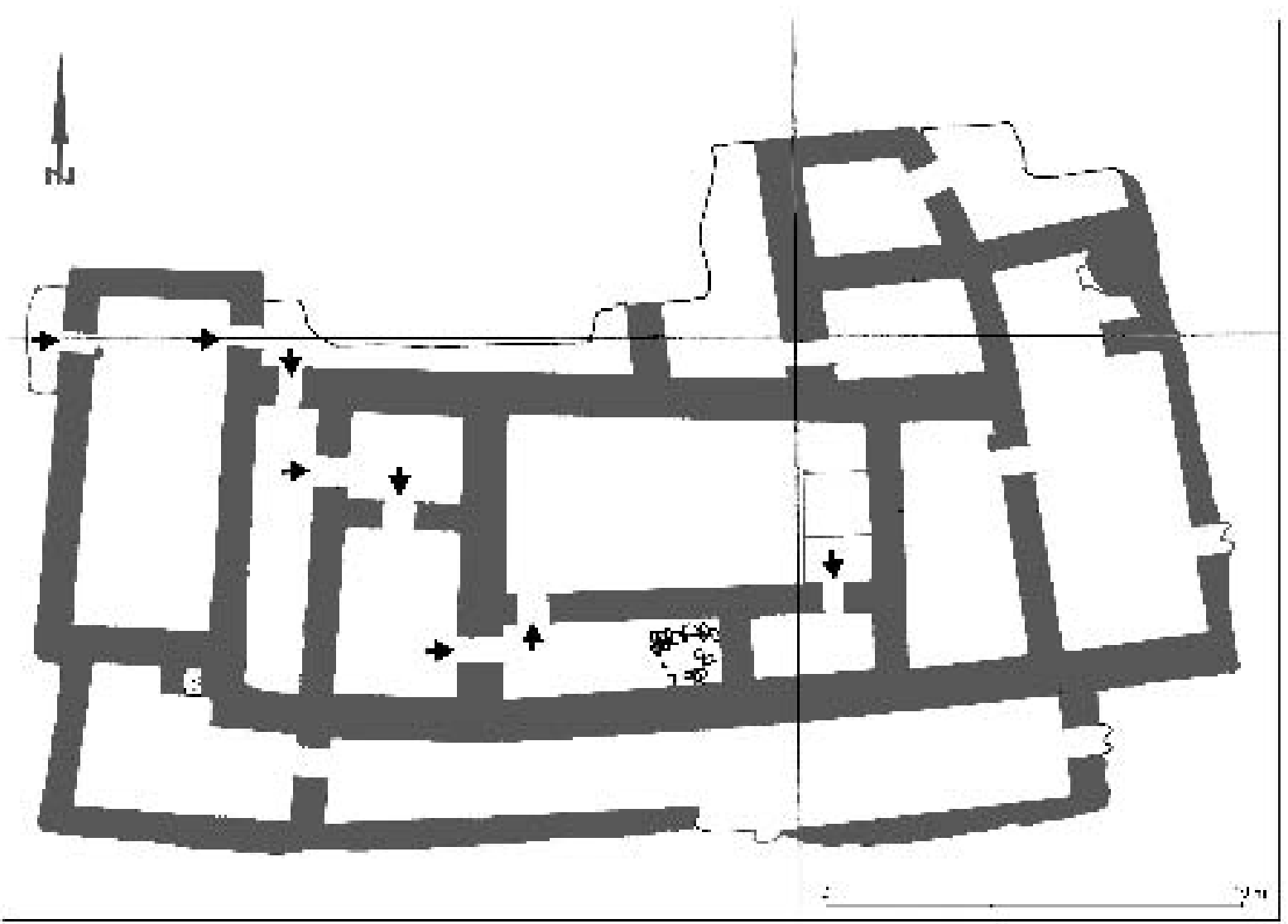

Fig. 15a The Abu Temple, compound with Archaic Shrine IVc at Tell Asmar (Eshnunna) (after HeINRICH, op. cit., fig. 154)

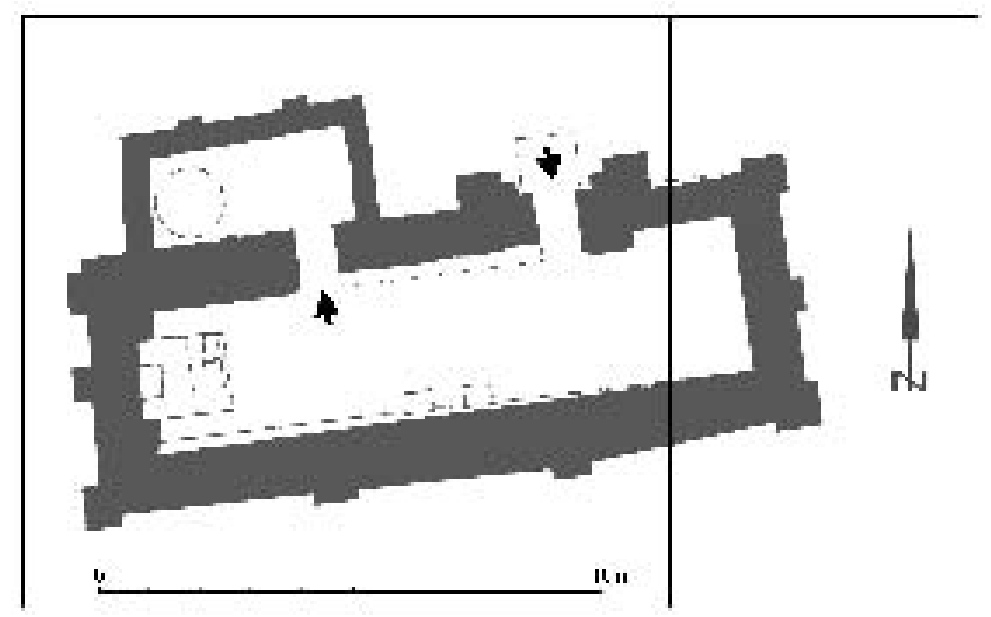

Fig. 15b The Abu Temple at Tell Asmar (Eshnunna) as single shrine-Temple (after HeINRICH, op. cit., fig. 186) 


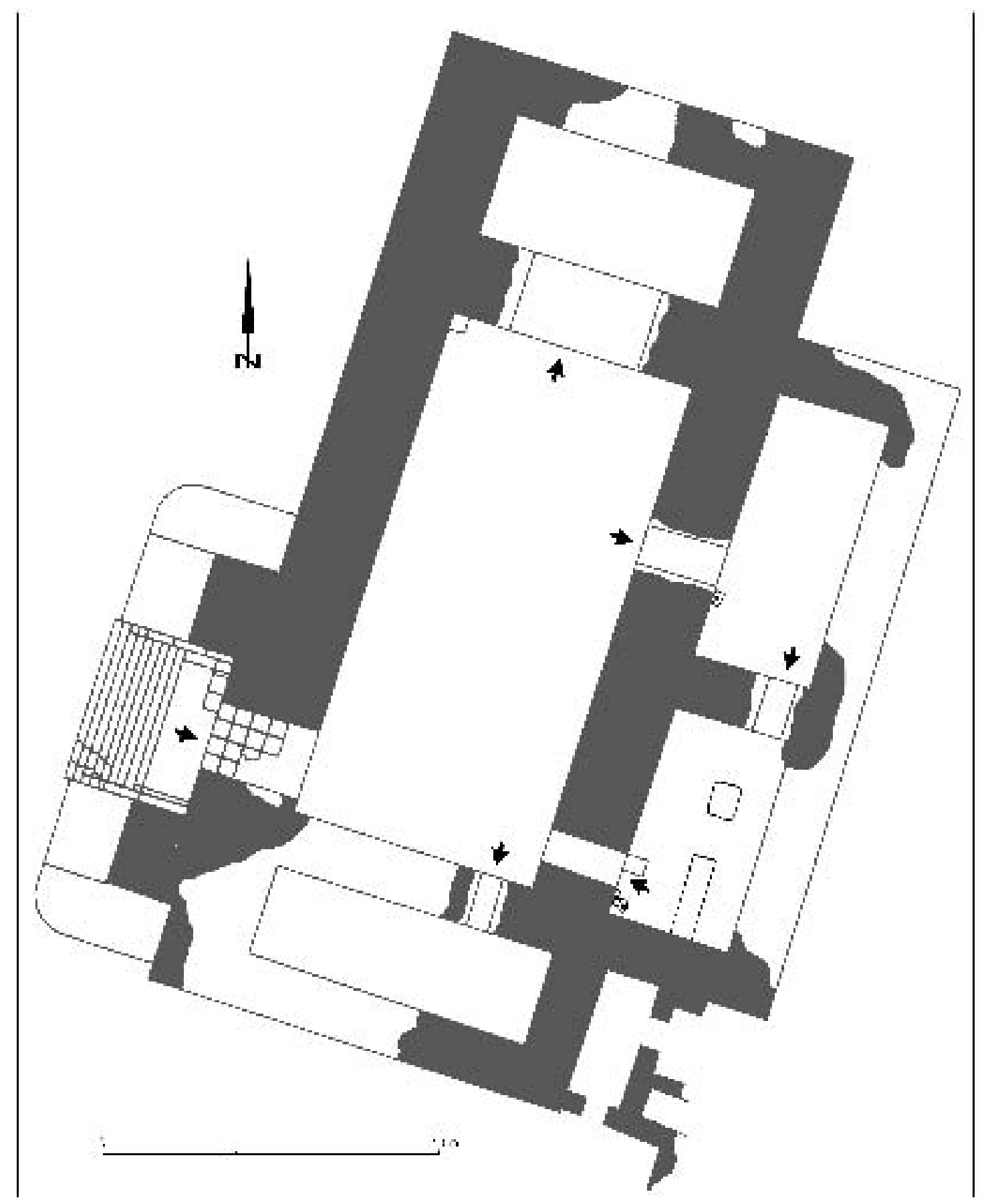

Fig. 16 Ishtar Temple in Assur, phase E (after HeINRICH, op. cit., fig. 243) 


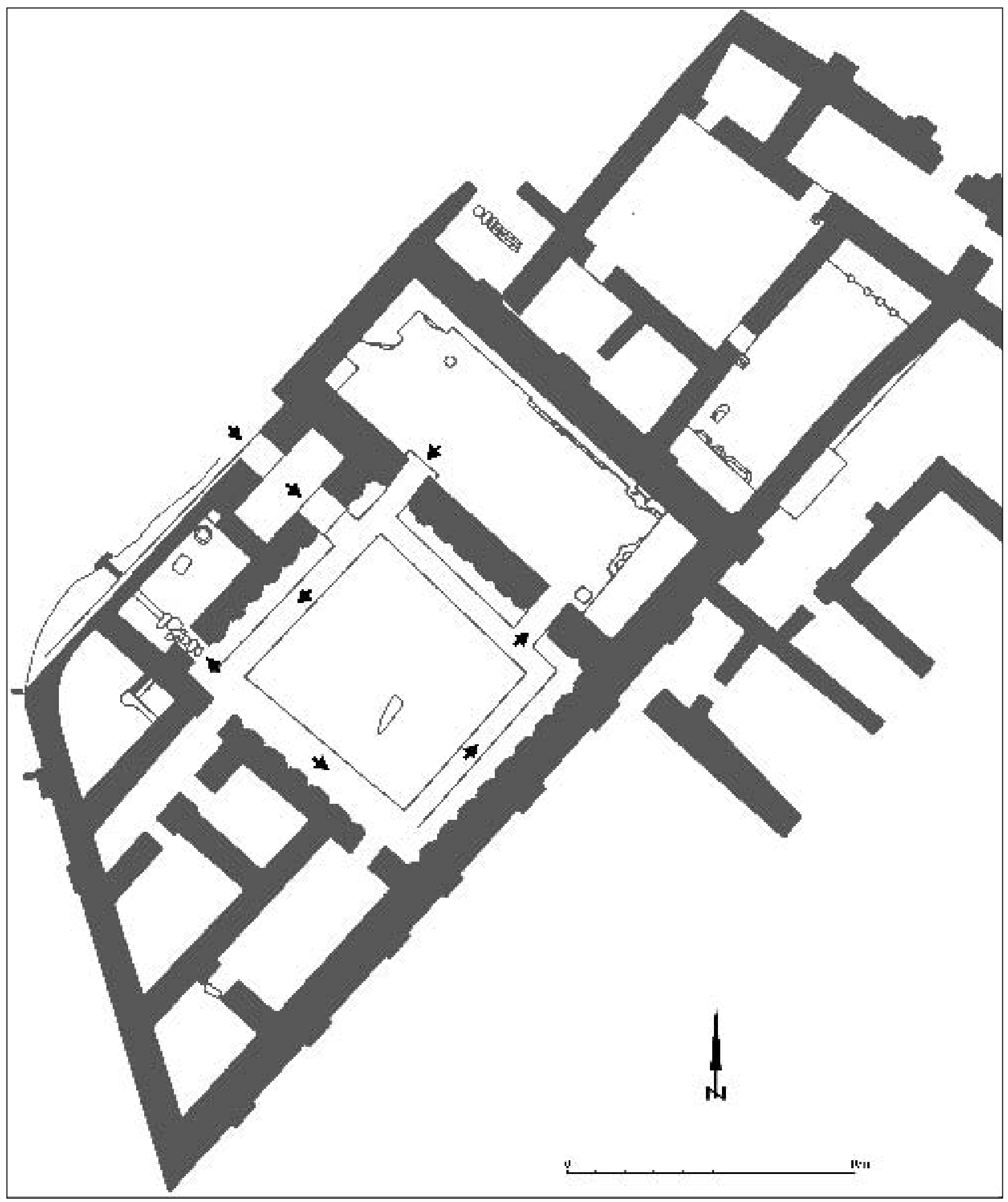

Fig. 17 Temple of Ishtarat and Ninni-Zazza (after HeInRICH, op. cit., fig. 197) 

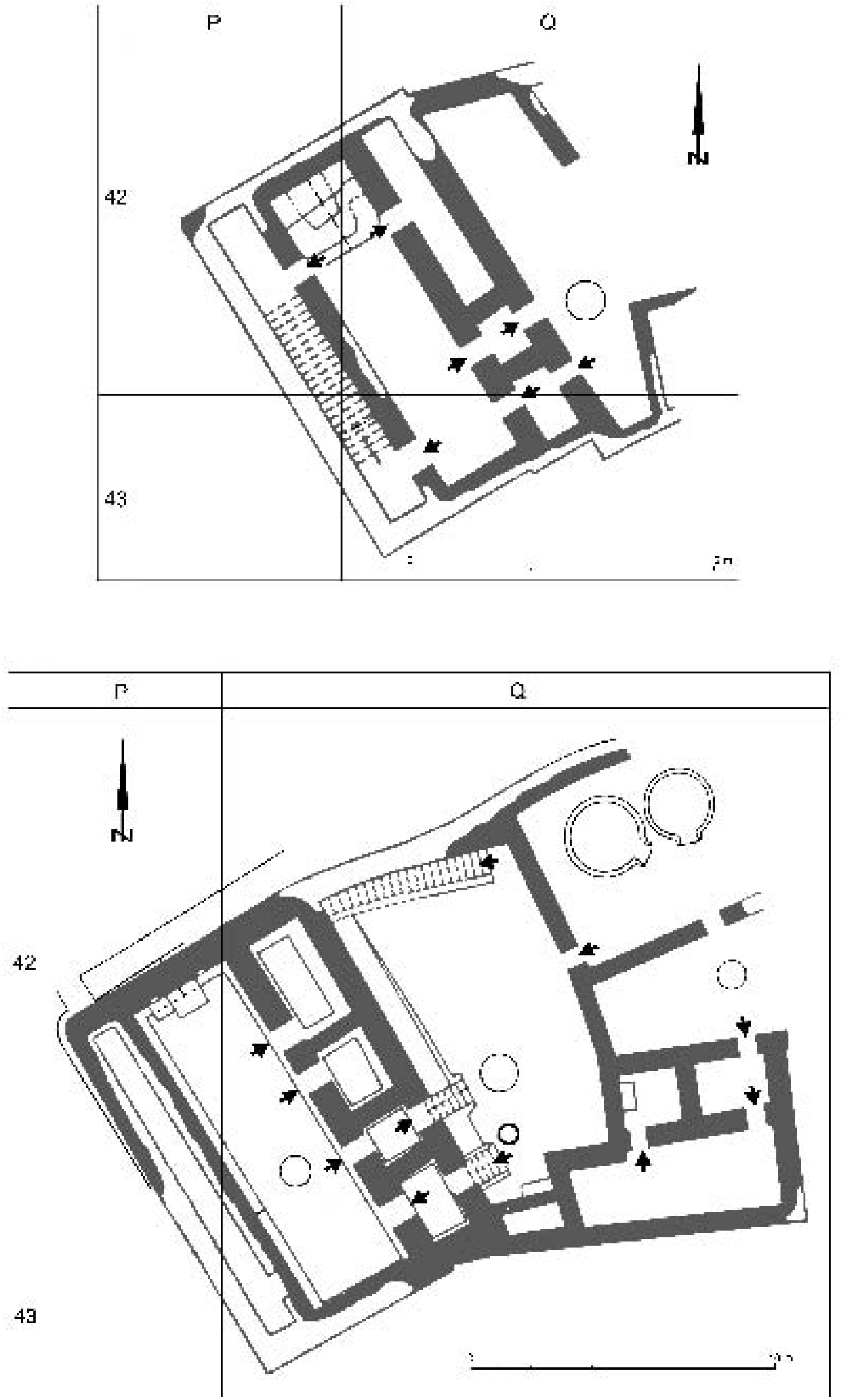

Fig. 18.1 Phases I and IV of the Sin Temple at Khafadja (after HeINRICH, op. cit., 93f., 121f., figs. 148, 149) 


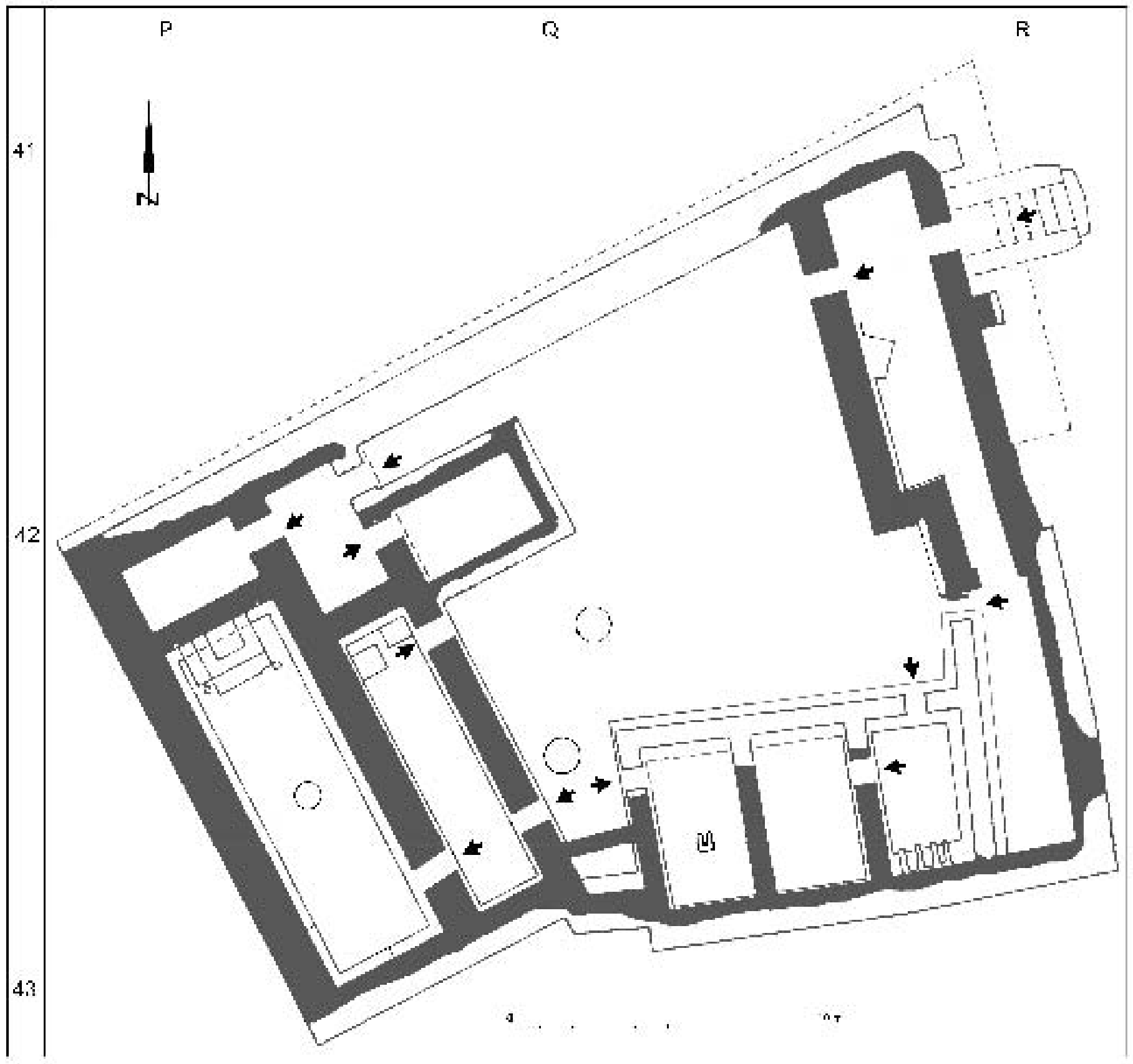

Fig. 18.2 Phase VI of the Sin Temple at Khafadja (after HeInRICH, op. cit., 93f., 121f., fig. 151) 


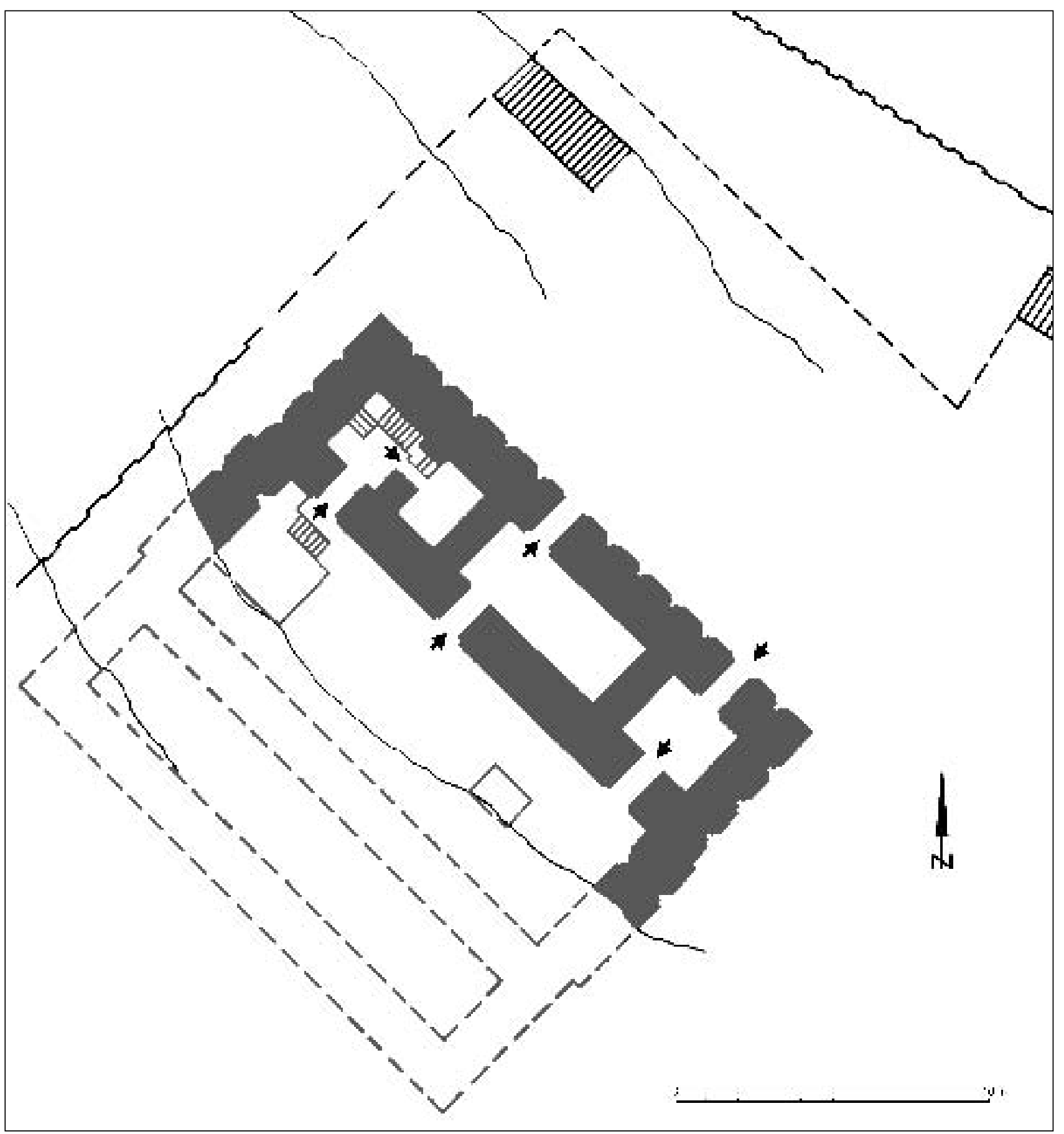

Fig. 19 Plan of the Painted Temple at 'Uqair (after HeInRICH, op. cit., fig. 105) 

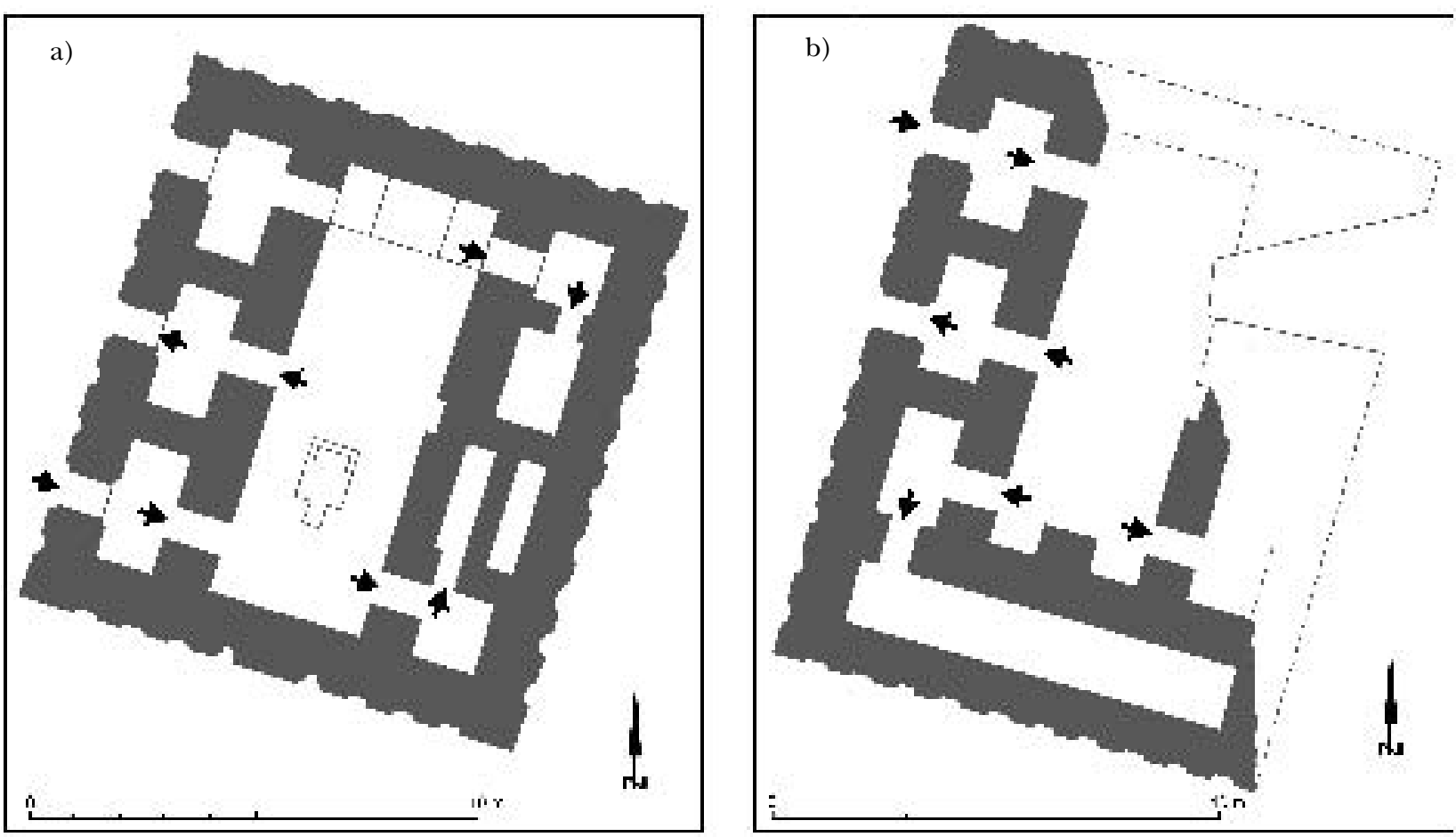

Fig. 20 The Red Temple (a) and the Grey Temple (b) at Gebel Aruda (after Werner, Sakralarchitektur, 116, 118)

ended in the temple with bent axis. ${ }^{48}$ Such a trend is traceable in the successive phases of the Sin Temple at Khafadja (Fig. 18.1, Fig. 18.2), from the Djemded Nasr until the Early Dynastic I Period testifying - as they do - to the emergence of the temple with bent axis - the Herdhaus - from the Mittelsaal Temple as Heinrich has suggested. ${ }^{49}$ The shrine itself is at the centre and has the typical bentaxis system with the entrance opening - across a vestibule in the usual east-north-east direction into a courtyard and a bent axis tailing off into the shrine to the north-north-west. Some of the temple phases (I-IV) have two entrances, most probably an entrance and exit likely to have been the result of a specific cult practice. An additional door near the cult podium leads into the sacristy/treasure-house. Phase VI also has two entrances, albeit only into the procella where additional cult podia were constructed. The three-stripe system with a staircase in the westernmost stripe degenerates into a blind cor-

\footnotetext{
48 HeinRich, n. 35.

49 Delougaz \& Lloyd, op.cit., pls. 2-6; Heinrich, op. cit., 93f., 121f., figs. 148, 149, 151, 173, 174.

50 G. VAN DRIEL, Een reconstructie van de tempels op de Jebel Aruda, Phonix 37 (1991), 21-31; P. Werner, Die Entwicklung der Sakralarchitektur in Nordsyrien und
}

ridor in phase IV, reminiscent of blind corridors behind the sanctuaries of other temples in the Levant, including our temple at Tell Ibrahim Awad. This reduces the temple into a two-stripe system, the shrine and the vestibule. The step from the Mittelsaalhaus to the Herdhaus - the bent-axis temple has been created.

A similar trend is also detectable in northern Syria and even earlier. The Mittelsaalhaus - or Uruk Temple was exported to the Upper Euphrates hand in hand with the Uruk colonisation, as can be evidenced by the Red Temple at Gebel Aruda. It has a triple entrance from west-north-west, leading across three vestibules into the cult room at the centre with a bent axis to the north-north-east (Fig. 20a).$^{50}$ The third door next to the altar could be expected to lead into a linked sacristy and not into the open court. North of it is the so-called Grey Temple that is the same type of Mittelsaalhaus with two entrances from the west-north-west (Fig. 20b).${ }^{51}$ Here the door

Südostkleinasien, vom Neolithikum bis in das 1. Jt. v. Chr., Münchner vorderasiatische Studien, ed. by B. HroudA XV, München-Wien 1994, 116f., pls. 34,1-36,2.

51 VAN DrIel, loc. cit.; Werner, op.cit., 116f., pls. 34.1, $36.1-2$. 


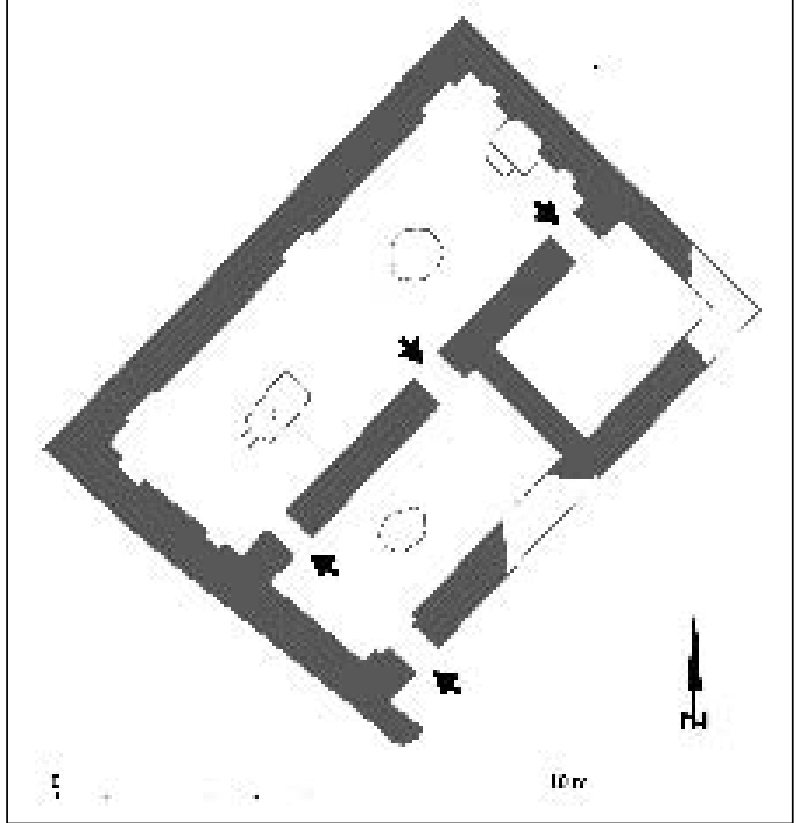

Fig. 21 Sanctuary S VIII at Gebel Aruda (after WERNER, op.cit., 122)

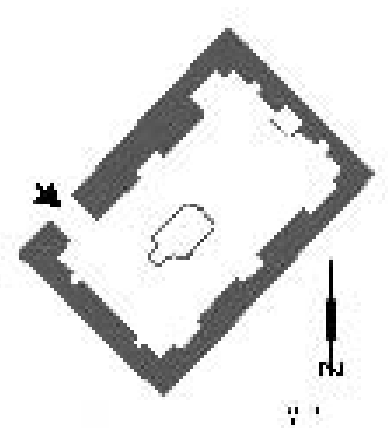

Fig. 22 Single-shrine temple with bent axis at Sheikh Hassan (after WERNER, op.cit., 121)

beside the cult-podium leads into a closed sacristy as customary. Both temples have the usual niched façade. Another such temple is known from the same area, namely at Tell Qannas, but with probably only one entrance and a bent axis to the right. ${ }^{52}$
52 A. Finet, Les temples sumériens du Tell Kannâs, Syria 52 (1975), 157-174; IDEM, Bilan provisoire des fouilles belges du Tell Kannâs, AASOR 44 (1979), 79-95; WERNER, op.cit., 118-120, pls. 37,1-38,1.

53 Cf. n. 35.

54 G. van Driel \& C. van Driel-Murray, Jebel Aruda, The 1982 Season of Excavation, Interim Report, Akkadica 33 (1983), 1-26; WERNER, op.cit., 122, pl. 41,1.

55 J. BoESE, Tell Sheikh Hassan 1990, Vorläufiger Bericht über
The trend of scale-down of the Mittelsaalhaus, as observed by HeinRich for Mesopotamia i.e. at Tell Khafadja $^{53}$ in the transition from Djemdet Nasr to Early Dynastic I Period can be found in northern Syria as early as the Uruk Period - again at Gebel Aruda, sanctuary S VIII (Fig. 21).$^{54}$ This building has only two stripes, the shrine and - in front - a stripe with a vestibule and a sacristy. One door from the courtyard in the south-east leads to the vestibule from where two doors through the south-eastern long wall lead into the shrine with a bent axis to the right. A third door in the same wall gives access to a sacristy near the cult podium. This monument is an important link in the architectural history. It may therefore be unsurprising to find in a new excavation at Tell Sheikh Hassan the first archetypal singleshrine temple with left- bent axis in the Upper Euphrates region (Fig. 22) ${ }^{55}$ It may date back to the Uruk Period.

This new evidence from northern Syria seems to suggest that this type of temple emerging out of the Mesopotamian Mittelsaal Temple went back from northern Syria to Mesopotamia. However, the problem is that we have no evidence of continuity from that place as the other temples with bent axis in northern Syria do not appear until the Akkadian Period $^{56}$ and later. ${ }^{57}$ It is interesting that a similar, perhaps coincidental gap in occurrences of the temples with bent axis, seems to have also existed in Palestine. There is an early example at Jericho level VII $^{58}$ at Early Bronze I (Fig. 10) and a very late example in the City Wall Temple at Ai from Early Bronze $\mathrm{IIIb}^{59}$ which might roughly have been contemporary with the temple at Tell Ibrahim Awad. The gap is only closed in Mesopotamia. That is why there may be some justification in the original suggestion that this type originates from that place.

Generally speaking, the temple with bent axis is very distinctive and it is not feasible that this type developed independently in Egypt, especially at a time when this model was used in the Near East. Not only is the preferred alignment towards the east

eine Grabungskampagne am Euphrat-Stausee, Saarbrücken 1990; WERNER, op.cit., 121, pl. 40,1-40,3. It is because of the niched wall inside the temple that WERNER assigns this building to the Uruk type of temple which normally have the Mittelsaalhaus plan.

56 Tell Brak, Tell Mozan see WerNER, op.cit., 124-127.

57 Ibidem, 126-128.

58 N. 27.

59 N. 28. 
shared at both regions. In Tell el-Dabca Temple II we have in addition the two doors through the façade, the far one leading into the shrine; the second one near the cult podium leading out of it - a layout we have reviewed above and common to several other temples in the Near East. Taking a closer look at the published plans of the temple at Tell Ibrahim Awad, an observer would have the suspicion that this shrine, too, had a second door through the middle of the eastern long wall, directly opposite the stepped platform in the middle of the rear wall (Fig. 6). ${ }^{60}$ This would make the east-west wall, due north of the suspected entrance in the passage leading to the northern entrance, a feasible proposition as a retaining wall against the dirt or screen. On closer inspection, this middle entrance, in conjunction with the stepped platform right behind in the middle of the rear wall, would represent an archetypal broadroom temple, typical of Canaan in the Early Bronze Age, i.e. at the same time. This may have also been the original concept of this temple's predecessors, all of which have the layout of a broadroom. ${ }^{61}$ The shrine of phase 2 also clearly shows the podium up against the centre of the rear wall ${ }^{62}$ - a feature that is otherwise uncommon in bent-axis temples that, as a rule, have the cult podium up against the small wall furthest from the entrance.

Taking all of the evidence together, it seems highly likely that phase 2c marked the change from a broadroom temple to the scheme of temple with bent axis. Although in the earlier phase this southern door is not visible it is perfectly possible that we

${ }^{60}$ Eigner, (n. 5) 19, fig. 2.

61 Ibidem, figs. 7-10. It seems that this second door had been walled up later.

62 Ibidem, 28, fig. 7 with plan of phase 2 ( $2^{\text {nd }}-3^{\text {rd }}$ Dyn.).

63 Ibidem, 30-36, figs. 7-10, pl. III.

${ }^{64}$ Ibidem, 35, phase 7 .

65 K. Kroeper \& D. Wildung, Minshat Abu Omar I, Ein vorund frühgeschichtlicher Friedhof im Nildelta: Gräber 1-114, Minshat Abu Omar II, Ein vor- und frühgeschichtlicher Friedhof im Nildelta: Gräber 115-204, Mainz 1994.

66 T. VON DER WAY, Untersuchungen zur Spätvor- und Frühgeschichte Unterägyptens, SAGA 8, Heidelberrg1993; IDEM, Buto I, Ergebnisse zum frühen Kontext, Kampagnen der Jahre 1983-1989, AV 83, Mainz 1997; preliminary reports of the author in: MDAIK 42 (1986), 191-212; MDAIK 43 (1987), 241-257; MDAIK 44 (1988), 283-306; MDAIK 45 (1989), 275-307. See also n. 68.

67 I. Finkelstein \& D. Ussishkin, in: Megiddo III The 1992-1996 Seasons, ed. by I. FinkelSTEIN, D. Ussishkin \& B. HALPERn, Inst. of Archaeology Monograph Series 18, Tel Aviv 2000, 170-176, 586f. The date of the cache of are at that level already in the foundations of the building. Both types of temple originate, however, from the Near East.

We can understand how this type of architecture came into Egypt in the late Middle Kingdom/Second Intermediate Period with the population of Near Eastern origin living at Tell el-Dabca. But how did this type of temple come into Egypt at the time of the Old Kingdom? The material culture during that period at Tell Ibrahim Awad was purely Egyptian and showed no Near Eastern component. There are two possible explanations.

1. The predecessors of the Old Kingdom temple at Tell Ibrahim Awad were also "Broadroom"-temples. ${ }^{63}$ As only their foundations were preserved, it is difficult to say whether they were just broadroom- or if they were bent-axis temples. Our analysis of the phase 2b-temple would favour the broadroom type and would take us back at least to the times of Dynasty 0 , probably earlier. ${ }^{64}$ The cemetery at Minshat Abu Omar $^{65}$ and the stratigraphic excavations at Buto ${ }^{66}$ show, that, at the time of Naqada IIc-d and Naqada III, the north-eastern Delta had become a part of a culture which originated in Upper Egypt and had spread out to varying degrees over all of Egypt. Longdistance trading ties with Canaan and even with Syria can be shown by imports, especially at a time when Egyptian culture was encroaching into southern Palestine in Dyn 0/1 with a probable outpost as far north as Megiddo. ${ }^{67}$ It is probably around that time that an adoption of Near Eastern specific architectural features was feasible. Thin terracotta $\operatorname{cones}^{68}$ very

Egyptianising pottery is not quite clear, but they should be dated to the Dyn. 0/1 horizon.

68 VON DER WAY, SAGA 8, fig. 19; IDEM, Buto I, pl. 57/1-8. The thin cones should not be mixed up with other stockier cones with concave base from earlier stratification, without any mudbrick architecture around. Lit. T. VON DER WAY, Zur Herkunft keramischer Dekorationen des spätvorgeschichtlichen Unterägypten“, CCE 2 (19911), 1-9; IDEM, Indications of Architecture with Niches at Buto, in: The Followers of Horus, Studies Hoffmann, ed. by R. Friedman \& B. AdAMs, Oxbow Monographs 20, Oxford 1992, 217-226; as no in situ brick architecture was found D. FALTings has raised doubts on the conclusions of introduction of Near Eastern niched architecture on the basis of pottery cones: see Faltings in D. Faltings \& E.C. Köhler. "Vorbericht über die Grabungen des DAI in Tell el-Faracin/Buto, MDAIK 52 (1996), 87-114; EADEM, Recent Excavations in Tell elFaracin/Buto: New Finds and their Chronological Implications, in: Proceedings of the $7^{\text {th }}$ International Congress of Egyptology. Cambridge, 3-9 September 1995, ed. by 
similar to those used in the wall mosaics of Uruk were found in Buto, phase IIb (corresponding to Naqada IId) and in Early Dynastic layers, making it possible to postulate links to mudbrick walls. ${ }^{69}$ As a result, a link with Syria/ Mesopotamia seems possible at that time, especially as a sherd of truly Amuq $\mathrm{F}$ with a spiral reserve slip was found in a Protodynastic context. ${ }^{70}$

Another period with an even stronger connection with the Levant, but not necessarily with north Syria and Mesopotamia, is the time of the preceding ButoMaadi Culture, contemporary with late Naqada I and Naqada IIa-b. At that time the Delta experienced a strong influence from neighbouring southern Canaan Chalcolithic Culture. ${ }^{71}$ Even a physical influx of population from southern Palestine, the bearers of specific architectural features - such as subterranean habitation in pit systems - and of cultural features, is considered likely. ${ }^{72}$ A connection to mudbrick architecture is, however, not proven for this period. Therefore an import of a specific architectural type in the Naqada IId-III Period is more feasible as a formal implant in the north-eastern Delta which persisted until the time of the Old Kingdom.

2. There is perhaps also another and even likelier explanation to be borne in mind which could even be combined with hypothesis $\mathrm{N}^{\circ} 1$. During the time of the Old Kingdom, foreigners of Near Eastern origin were engaged as soldiers in such numbers in Egypt that, in writing, the classifier for soldiers could be changed to the image of Near Easterners. ${ }^{73}$ Even the classifier for the god Osiris appearing in the $5^{\text {th }}$ Dynasty represents the image of an Asiatic, ${ }^{74}$ perhaps a sign that important aspects of the cult of this god of vegetation were introduced with people from the Near East.

This occurred not only in the army but also in the Egyptian Navy at the time of the $5^{\text {th }}$ Dynasty and possibly even before sailors from the Levant were recruited.$^{75}$ It is not unfeasible that such people were stationed in the north-eastern Nile Delta in areas suitable for harbour employment, as happened from the time of the late Middle Kingdom onwards. ${ }^{76}$ Such people, although completely Egyptianised in their material culture, could have kept in their religious rites their own traditional features and may have introduced into this region the Near Eastern type of temple. The tradition of the temple at this site back to late prehistoric times seems to support a long history of peoples of Asiatic origin living in this area. It is possible that they served in dynastic times as soldiers and sailors, a tradition which was resumed at the time of the $12^{\text {th }}$ Dynasty and afterwards in the region of Tell el-Dabca-Qantir, culminating in a sacred precinct with two Ancient Near Eastern temples, including another bent-axis temple. ${ }^{77}$

\section{Acknowlegdement}

Graphic treatment of the illustrations if not stated otherwise by Nicola Math.

C. EYRE, OLA 82, Leuven 1998, 365-375; EADEM, Ergebnisse der neuen Ausgrabungen in Buto, in: Stationen, Beiträge zur Kulturgeschichte Ägyptens, Festschrift für Rainer Stadelmann zur Vollendung des 65. Lebensjahres, ed. by H. Guksch \& D. Polz, Mainz 1998, 35-45. Parallels with the Ghassulian Culture were shown, with which Buto I had strong connections.

69 Faltings, OLA 82, 375.

70 E.C. KÖHLER, Tell el-Faracîn - Buto III, Die Keramik von der späten Naqada-Kultur bis zum frühen Alten Reich (Schichten III bis VI), AV 94, Mainz 1998, pls. 68, 74.

71 I. Riskana \& J. SEeher, Maadi III, The Non-lithic Small Finds and the Structural Remains of the Predynastic Settlement, AV 80, Mainz 1989, 79f.; T. VON DER WAY, Untersuchungen zur Spätvor- und Frühgeschichte Unterägyptens, SAGA 8, Heidelberg 1993, 69-75.

72 Ibidem

73 R. Shalomi-Hen, The Writing of Gods: The Evolution of Divine Classifiers in the Old Kingdom, unpublished dissertation, The Hebrew University, Jerusalem 2003;
I would like to thank Racheli Shalomi-Hen for providing me information on her studies; see also Urk. I 104:1; P. PiACENTINI, L'autobiografia di Uni, principe e governatore dell'alto Egitto, Monografie di Studi di Egittologia et di Antichitá Puniche, Series minor 1, Pisa 1990, 11 (column 26 of the inscription).

74 Shalomi-Hen, op. cit.

75 M. Bietak, Zur Marine des Alten Reiches, in: Pyramid Studies and other Essays presented to I.E.S. Edwards, ed. by J. Baines, H. James, A.F. Shore \& A. Leahy, London 1988, 35-40.

${ }^{76}$ For the harbours of Avaris and Piramesse, and most likely Peru-nefer situated only about $7 \mathrm{~km}$ south of Tell Ibrahim Awad see L. HABACHI, Tell el-Dabca I, 106f.; M. BIETAK, Tell el-Dabca II. Der Fundort im Rahmen einer archäologisch-geographischen Untersuchung über das ägyptische Ostdelta. UZK I, Vienna 1975, ; M. BIETAK, Was Peru-nefer situated at Avaris? (in preparation).

77 Supra, n. 4. 